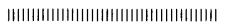

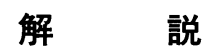

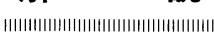

Agrochemistry and Biology Series

光学活性農薬開発の現状と展望

宮 崎 昭 雄

大阪府立農林技術センター

(平成 9 年 2 月 20 日受理)

\title{
Progress and Prospects of Optically Active Pesticides
}

\author{
Akio MIYAZAKI \\ Agricultural and Forestry Research Center of Osaka Prefecture, Shakudo, Habikino 583, Japan
}

\section{は じめに}

生物体の構成成分を分子レベルからみると，すべてにキ

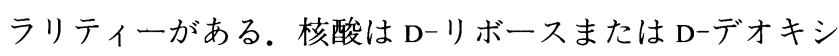
リボースを含み，タンパクを構成するアミノ酸はすべて L 型であり, 細胞膜を構成するリン脂質は L-3-グリセロリン 酸の立体構造をもつ. また，エネルギー代謝の基質は $\mathrm{D}^{-}$グ ルコースであって，L-グルコースの存在は知られていな い. 一方，生物に活性を示す医農薬の多くはキラル化合物 であり，これまで研究された例をみると，鏡像体間で生理 活性が異なる場合が多く知られている。これは当然ともい えることであって，活性物質が活性発現の場となる生物側 のキラルなリセプターとの接点において, 光学的性質が重 要となるのは合理的である．しかしながら，過去の合成医 農薬品の創製をみると，光学的性質を考慮せずに，キラル 化合物であってもラセミ体として開発されたのが実体で あった。

ラセミ体を使用したことに起因する悲劇的な例としてサ リドマイドをあげることができる。サリドマイドはつわり を抑之るラセミ型医薬品として妊婦に投与されたが，その 結果両手のない胎児の出現を招いた。1979 年 Blaschke ら ${ }^{11}$ はキラル HPLC を用いてその両鏡像体を光学分割し, 生物 活性を調べた結果, 天然のグルタミン酸と同じ絶対立体構 造をもつ $(S)-($-)-体のみに催奇性があることを見出した (その後の研究によれば, 光学活性サリドマイドは生理条件 下で容易にラセミ化すること, Blaschkeらの報告が唯一で 追試例がないことなどから， $(R)-(+)$-体のみを服用した場 合でも催奇性がなかったかどうか疑問視されている ${ }^{21}$. し かしながら，本問題を契機としてこの頃より生物活性と光 学異性との関係に, にわかに関心がもたれるようになり,
ラセミ型医薬の光学分割あるいは光学活性医薬品の合成が 活発に行なわれるようになった，また，医薬品のみならず， 昆虫ホルモンやフェロモンについても合成的手法を用いて 精力的に追求され, 興味ある新事実が続々と発見されてい る.これらキラル生物活性化合物に関する研究の進歩を技 術的側面からみれば，キラル HPLC 用充填剂の開発とな $\eta$, また新しい不斉合成試薬の開発や新規不斉反応の創出 として，うかがい知ることができる.

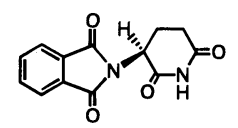

(S)-(-)-thalidomide

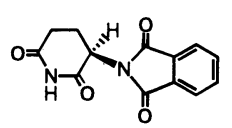

$(R)$-(+)-thalidomide
一般に，キラルな医農薬剤が生物に投与された際，目的 と寸る生物活性の発現に鏡像体間で差異の生じること以外 にも, 鏡像体間で差異が問題となるのは哺乳動物への毒性, 体内への吸収, 移行, 代謝, および脱離などがある. した がってラセミ体の代わりに, 光学活性体を用いれば, 必要 とする薬効のみを選択的に取り出すことができるばかりで なく，マイナスとなる生体内への蓄積や毒性などを軽減す る可能性も期待できる（医薬品分野では “racemic switches” という．後述). 実際, 医薬分野における chiral drugs の開 発はめざましく, 1994 年の世界市場において前年の $27 \%$ 増 の売り上げを示した $\left(\right.$ Table 1) ${ }^{3)}$.

現在わが国において, 登録・使用されている光学活性農 薬は抗生物質やジベレリンのような天然化合物を除くと非 常に少ない. その理由は, もともと光学活性の重要性につ いての認識が浅かったことに加えて, 光学活性体の合成に はラセミ体の合成に比べ多大の工程と費用を要すること, 光学活性体を製品化しても生物活性が倍増する程度ではコ 
ストの障害が大きすぎることなどがあげられる，現在登録 されている光学活性合成農薬を Fig. 1 に示すが，わずかに

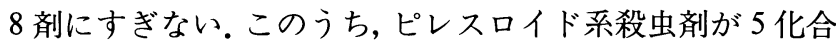
物もあるのは，もともとキラルな天然ピレスロイドの構造 変換を基礎としてきわめて活性の高い化合物にたどり着い た研究の歴史の結果と考之られる.

本稿では, 日本における光学活性農薬開発の現状と展望 について以下に述べる。

\section{キラルな合成農薬の両鏡像体間の生物活性}

現在日本で登録されている合成農薬は 400 以上ある。そ のうちで分子のなかにキラル構造を有する化合物は 82 種 あり (1996 年 6 月末現在)，それらを Fig. 1 および 2 に示 す。それらのなかで，Fig. 1 に示した 1 8 の化合物のみが 光学活性農薬として登録・使用されているだけである.

Table 1 Worldwide sales of enantiopure drugs growing at double digits. ${ }^{3)}$

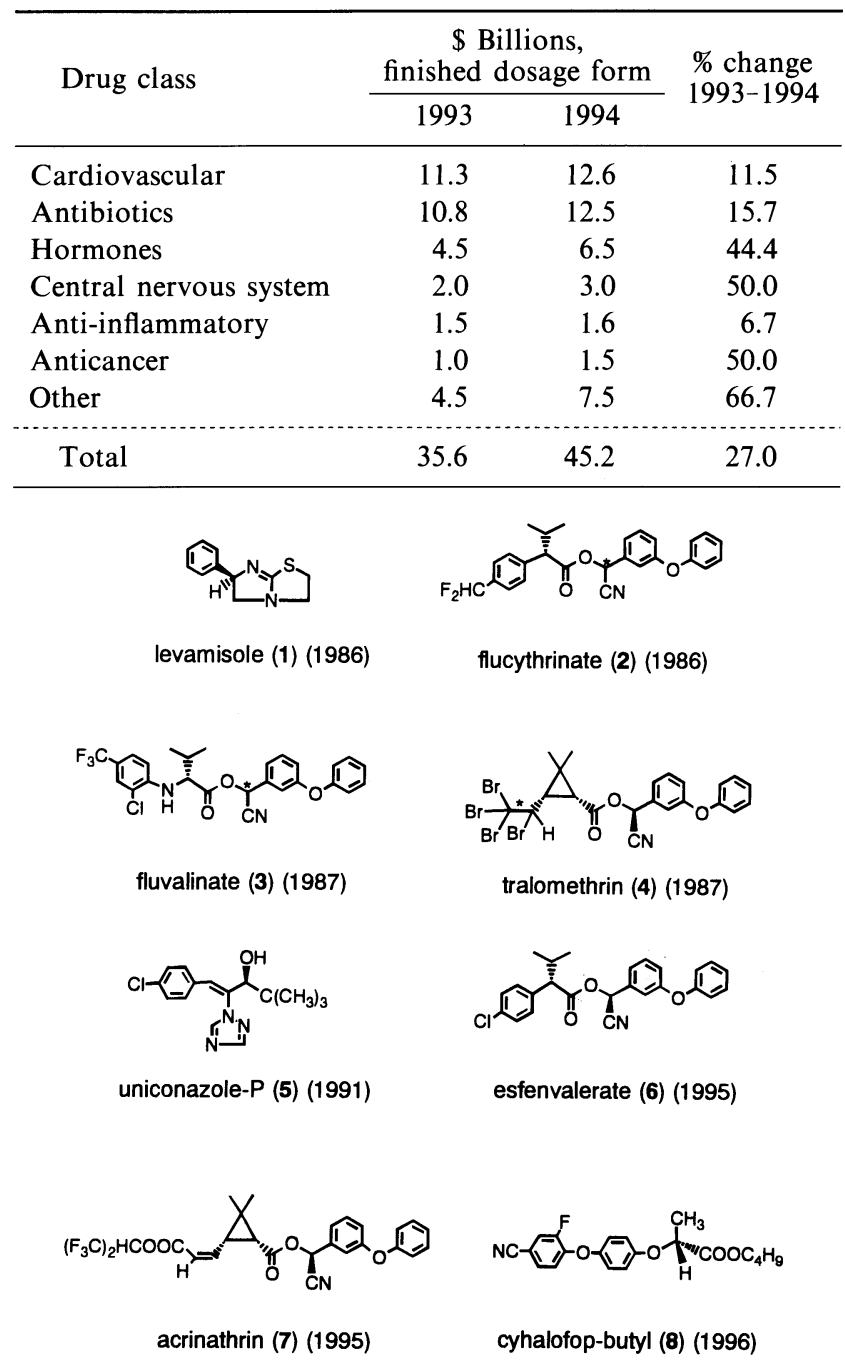

Fig. 1 Optically active synthetic pesticides that have been registered in Japan (1996).
82 種のキラル合成農薬のうちで, 光学活性体の調製法や 鏡像体間の生物活性について報告のあるものは，およそ半 数の 45 化合物である. それらの報告にもとづいて, 鏡像体 （含ジアステレオマー）と生物活性の関係をまとめると,

（1）一方の鏡像体には活性があるが，他方にはない (あってもきわめて低い)，

（2）両鏡像体間にそれほど大きな活性の差がない（数 倍 10 倍以内),

（3）両鏡像体がほぼ同等の活性を有する,

（4）鏡像体間で質的に異なった生物活性を有する, の四つに大別できる(Table 2).

最初に，一方の鏡像体が活性を示す例として，ピレスロ イド系殺虫剤について述べる. シクロプロパンカルボン酸 系ピレスロイドである allethrin (73) や tralomethrin (4), 非 シクロプロパンカルボン酸系ピレスロイドである esfenvalerate (6), flucythrinate (2) および fluvalinate (3)など は，Fig. 3 に示した絶対立体構造がもっとも殺虫活性が強 い.シクロプロパンカルボン酸部分の活性発現には $(1 R) の$ 立体配置が必要である.73 は天然型と同じ $(1 R, 3 R)$-trans$\alpha S$-菊酸エステルがもっとも殺虫活性が高く，そのジアス テレオマーである $[(1 R, 3 S)-c i s-\alpha S]$-体にも約 $1 / 2$ の活性

$\begin{aligned} \text { No. } & \text { compound name } \\ 9 & \text { prothiofos (I) } \\ 10 & \text { sulprofos (I) } \\ 11 & \text { profenofos (I) } \\ 12 & \text { pyraclofos (I) } \\ 13 & \text { acephate (I) } \\ 14 & \text { isofenphos (I) } \\ 15 & \text { amiprofos-methyl (H) } \\ 16 & \text { butamifos (H) } \\ 17 & \text { EPN (I) } \\ 18 & \text { fosthiazate (I) } \\ 19 & \text { vamidothion (I) } \\ 20 & \text { oxydeprofos (I) } \\ 21 & \text { malathion (I) } \\ 22 & \text { phenthoate (I) } \\ 23 & \text { naled (I) } \\ 24 & \text { trichlorfon (I) } \\ 25 & \text { pyrazophos (F) } \\ 26 & \text { mesulfenfos (I) } \\ 27 & \text { fenobucarb (I) } \\ 28 & \text { metolachlor (H) } \\ 29 & \text { metalaxyl (F) } \\ 30 & \text { triadimefon (F) } \\ 31 & \text { bitertanol (F) } \\ 32 & \text { paclobutrazol (PGR) } \\ 33 & \text { cyproconazole (F) } \\ 34 & \text { tebuconazole (F) } \\ 35 & \text { myclobutanil (F) } \\ 36 & \text { hexaconazole (F) } \\ 37 & \text { propiconazole (F) } \\ 38 & \text { difenoconazole (F) } \\ 39 & \text { ipconazole (F) } \\ 40 & \text { pefurazoate (F) } \\ 41 & \text { vinclozolin (F) } \\ 42 & \text { fenarimol (F) } \\ 43 & \text { ancymidol (PGR) } \\ 44 & \text { flurprimidol (PGR) } \\ 45 & \text { inabenfide (PGR) } \\ & \end{aligned}$

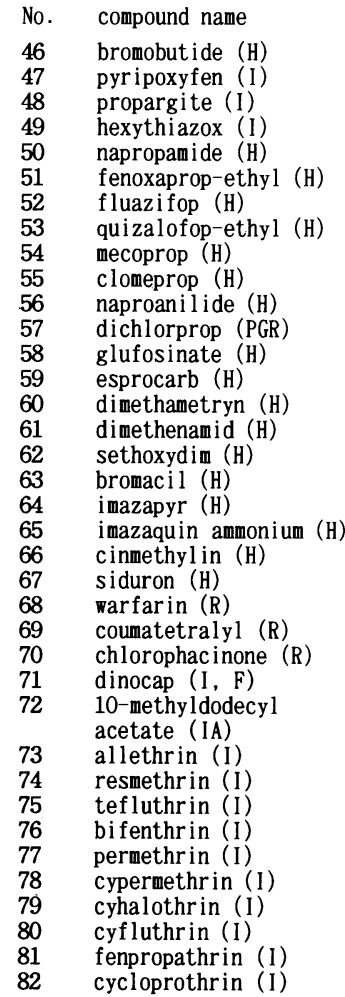

Fig. 2 Chiral pesticides registered in Japan (1996, the chemical structures are shown on the following 2 pages).

a) Classification of pesticides in parentheses. I : insecticide, $\mathrm{F}$ : fungicide, $\mathrm{H}$ : herbicide, PGR : plant growth regulator, $R$ : rodenticide, IA : insect attractant (72 is a component of smalure) 


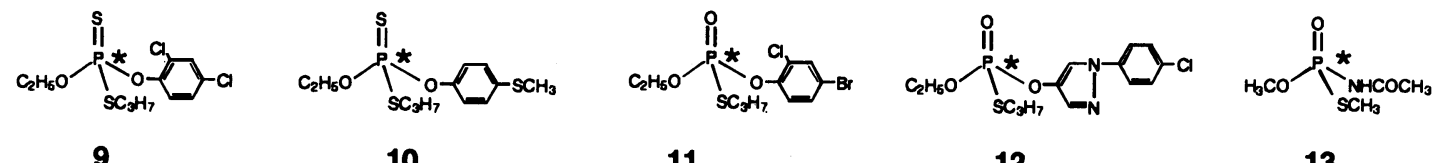

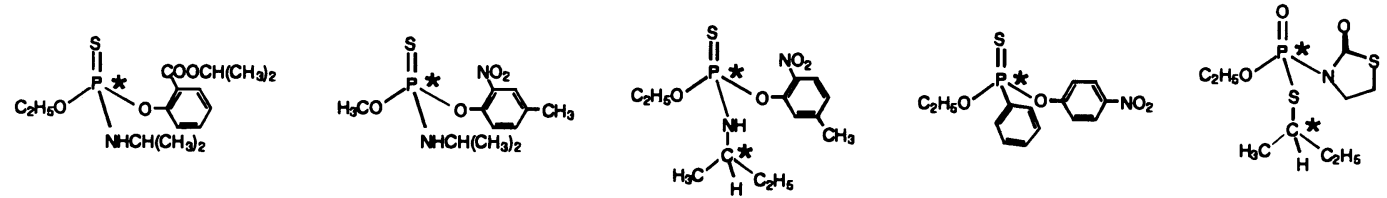

14

15

16

17

18

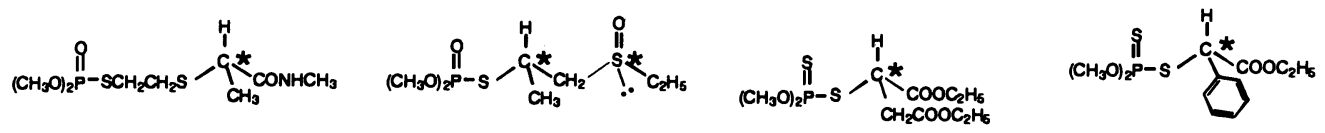

19

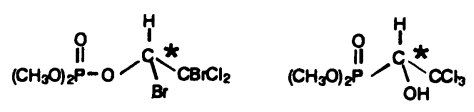

23

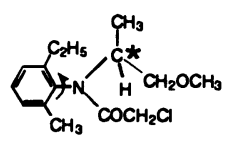

28

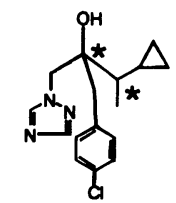

33

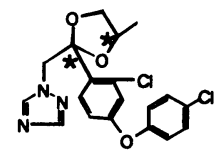

38<smiles>COC1CC2CC1CC(C(O)(C1CC1)C1CC1)C2</smiles>

43

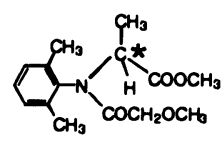

29<smiles>CC(C)=CN1CNC1</smiles>

34

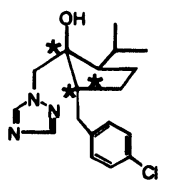

39<smiles>CCC(O)(c1ccc(OC)cc1)C1CNNN1</smiles>

44

20

21

22

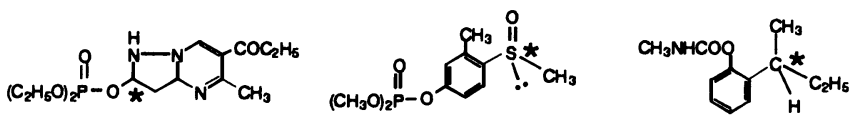

25

26

27

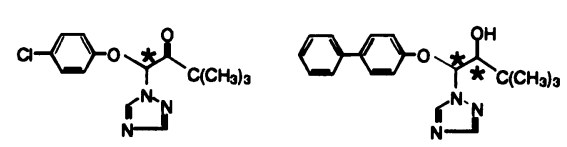

30

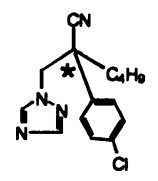

35

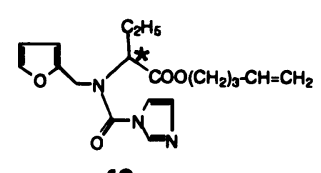

40

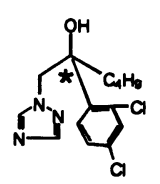

36

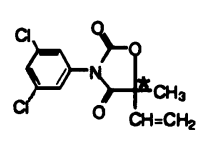

41<smiles>CC(C)=C(C(O)C1CCC(Cl)CC1)N1CNC1</smiles>

32

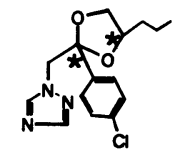

37

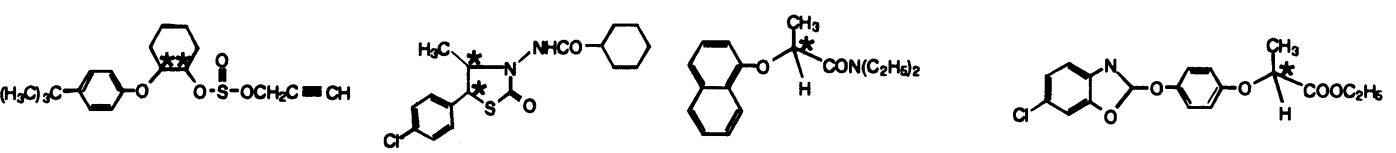

48

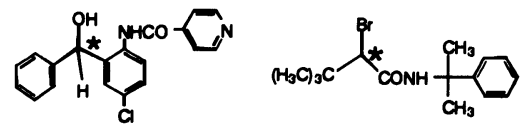

46

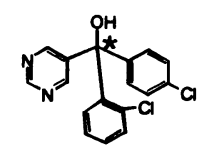

42 
Journal of Pesticide Science 22 (2) May 1997

139

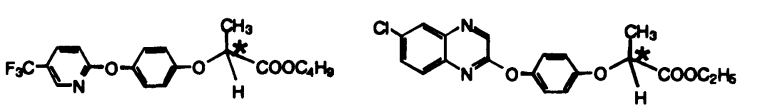

52

53

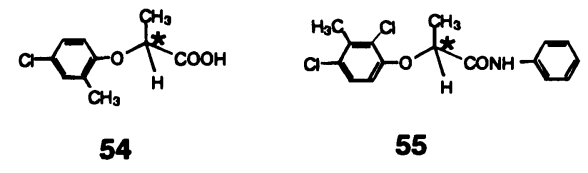

$\cos 20$

56

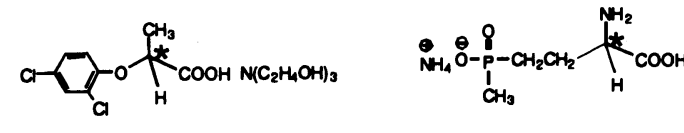

57

58

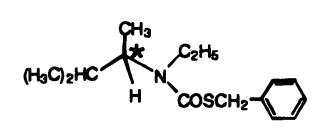

59

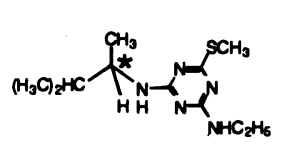

60

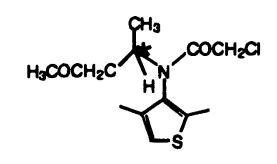

61

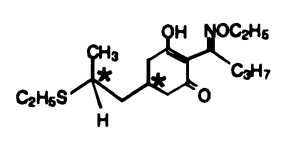

62

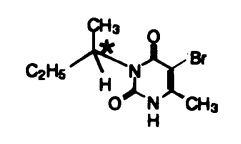

63

64

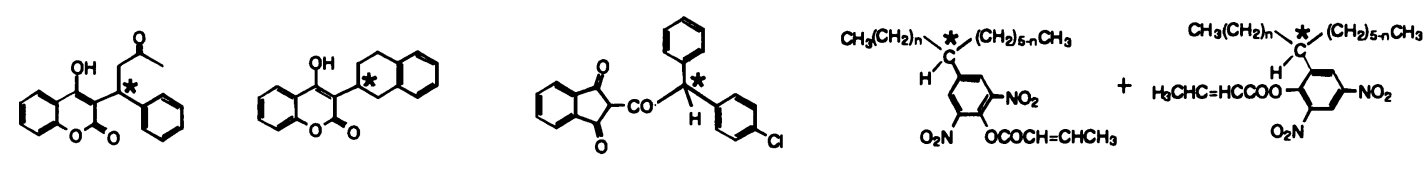

68

69

$71 n \leq 5$

${ }_{72}{ }_{73}$

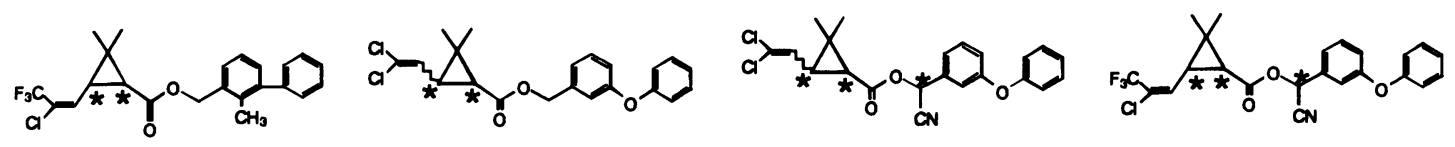

76

77

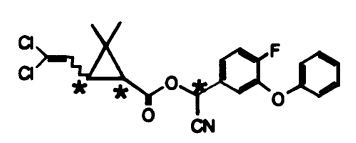

80

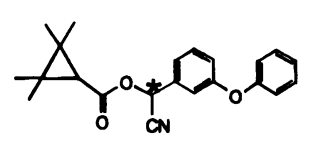

81
78

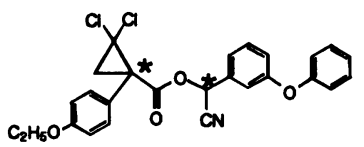

79

82 
Table 2 Relationship between enantiomers (diastereomers) and biological activity.

\begin{tabular}{|c|c|}
\hline Type of biological activity & Compound \\
\hline $\begin{array}{l}\text { One enantiomer is strongly active, another, in- } \\
\text { active or very slight }\end{array}$ & $\begin{array}{l}\text { Pyrethroid insecticides }(\mathbf{2}-\mathbf{4}, \mathbf{7 3}-\mathbf{8 2}) \text {, 2-phenoxypropionic acid } \\
\text { derivatives }(\mathbf{9}, \mathbf{5 2}-\mathbf{5 4}, \mathbf{5 6}, \mathbf{5 7}) \text {, tebuconazole }(\mathbf{3 4}) \text {, inabenfide }(\mathbf{4 5}) \text {, } \\
\text { hexythiazox }(\mathbf{4 9}) \text {, glufosinate }(\mathbf{5 8})\end{array}$ \\
\hline $\begin{array}{l}\text { Difference in activity between both enantiomers } \\
\text { is slight (the difference is within } 4-10 \text { times) }\end{array}$ & $\begin{array}{l}\text { Levamisole }(\mathbf{1}) \text {, cyhafop-butyl }(9) \text {, organophosphorus compounds } \\
(\mathbf{1 0}, \mathbf{1 1}, \mathbf{1 3}, \mathbf{1 4}, \mathbf{2 1}, \mathbf{2 2}) \text {, metalaxyl }(\mathbf{2 9}) \text {, ipconazole }(39) \text {, pefurazoate } \\
(\mathbf{4 0}) \text {, bromobutide }(\mathbf{4 6}) \text {, napropamide }(\mathbf{5 0}) \text {, warfarin }(\mathbf{6 8}), 10- \\
\text { methyldodecyl acetate }(\mathbf{7 2})\end{array}$ \\
\hline Both enantiomers have comparable activtiy & Triadimefon $(\mathbf{3 0})$ \\
\hline Each enantiomer has different type of activity & $\begin{array}{l}\text { Uniconazole-P (5), esfenvalerate (6), EPN (17), metolachlor (28), } \\
\text { paclobutrazol (32), propiconazole (37) }\end{array}$ \\
\hline
\end{tabular}

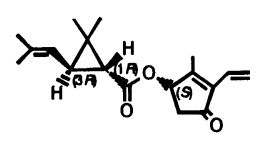

73

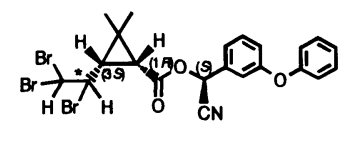

4

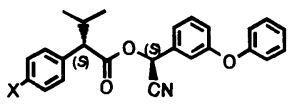

2: $\mathrm{X}=\mathrm{CHF}_{2}, 6: \mathrm{X}=\mathrm{Cl}$,

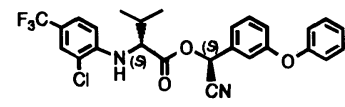

Fig. 3 The most insecticidal enantiomers of allethrin (73), tralomethrin (4), flucythrinate (2), fenvalerate (6) and fluvalinate (3).

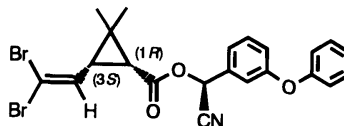

deltamethrin

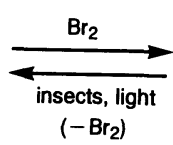

$\left.-\mathrm{Br}_{2}\right)$

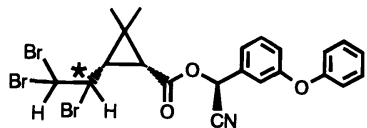

tralomethrin (4)

Fig. 4 Preparation of tralomethrin (4) and reproduction of deltamethrin.

があった。しかし，73 の鏡像体の $[(1 S, 3 S)$-trans- $\alpha R]-$ 体 には $1 / 200$ の活性しかなかった. 73 の 8 種の立体異性体の イエバエに対する殺虫力を Table 3 に示す4).

4 は deltamethrin の臭素付加生成物で, 4 位の不斉炭素に ついてはエピ体であるが, 昆虫体内で脱臭素化されて生成 する deltamethrin が活性の本体と考えられている（Fig. 4) ${ }^{5)}$.なお, deltamethrin は $[(1 R, 3 S)-c i s-\alpha S]$-体がもっと も活性が強く, $[(1 R, 3 S)-c i s-\alpha R]-$ 体にも活性があったが, 他の六つの立体異性体は不活性であった ${ }^{6)}$.

非シクロプロパンカルボン酸系ピレスロイドの場合は, 酸側が $(S)$ ，アルコール側が $(S)$ の絶対配置を有する鏡像 体 $(2 S, \alpha S)$ がもっとも殺虫活性が強く, その鏡像体 $(2 R$, $\alpha R)$ にはほとんど活性がない7). Esfenvalerate (6) の酸部分 の絶対配置 $(2 S)$ が高い殺虫活性を有することは, 天然の菊 酸の絶対立体構造に類似性があると報告されている（Fig. $5)^{8)}$. 他方, ジアステ.レオマー $(2 S, \alpha R)$ にも, 6 のほぼ $1 / 10$ の活性がある(Table 4). 合成ピレスロイドについての詳細 は成書を参考されたい9).

フェノキシ酸系除草剂には，低濃度では植物ホルモンの 一種 IAA と同じホルモン作用を有し, 高濃度ではホルモン 作用の擋乱を起こして除草活性を発揮する夕イプと, 脂肪 酸の生合成酵素（Acetyl-CoA carboxylase, ACC）を阻害す る夕イプの 2 種類がある. 前者の夕イプは mecoprop (54)
Table 3 Insecticidal activities of eight stereoisomers of allethrin (73) against housefly. $\left.{ }^{4}\right)$

\begin{tabular}{|c|c|c|c|}
\hline \multicolumn{2}{|c|}{ Stereochemistry of } & \multirow{2}{*}{$\begin{array}{c}\mathrm{LD}_{50} \\
(\mu \mathrm{g} / \mathrm{fly})\end{array}$} & \multirow{2}{*}{$\begin{array}{c}\text { Relative } \\
\text { activity }\end{array}$} \\
\hline Chrysanthemic acid & Alcohol & & \\
\hline$(1 R, 3 R)$-trans- & $(S)$ & 0.24 & 100.0 \\
\hline$(1 R, 3 S)-c i s-$ & $(S)$ & 0.41 & 58.5 \\
\hline$(1 R, 3 R)$-trans- & $(R)$ & 1.31 & 18.3 \\
\hline$(1 R, 3 S)-c i s-$ & $(R)$ & 1.71 & 14.0 \\
\hline$(1 S, 3 R)-c i s-$ & $(S)$ & 3.30 & 7.3 \\
\hline$(1 S, 3 S)$-trans- & $(S)$ & 4.96 & 4.84 \\
\hline$(1 S, 3 R)-c i s-$ & $(R)$ & 7.02 & 3.42 \\
\hline$(1 S, 3 S)$-trans- & $(R)$ & 45.2 & 0.53 \\
\hline
\end{tabular}

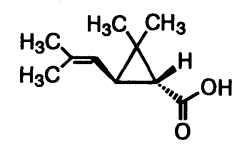

$(1 R, 3 R)$-trans-chrysanthemic acid

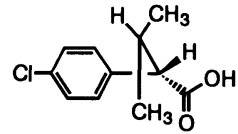

(S)- $\alpha$-isopropyl-4-chlorophenylacetic acid
Fig. 5 Similarity of the absolute stereochemistry between the most insecticidal chrysanthemic acid and phenylacetic acid analog.

や naproanilide (56)のような phenoxy-2-propionic acid 構 造をもち, 後者は fluazifop (52)や quizalofop-ethyl (53)のよ うな 4-aryloxyphenoxy-2-propionic acid 構造である. 両夕 
Table 4 Biological activities of four stereoisomers of esfenvalerate (6).

\begin{tabular}{|c|c|c|c|c|c|c|}
\hline \multicolumn{2}{|c|}{ Stereochemistry in } & \multirow{2}{*}{$\begin{array}{l}\text { Insecticidal } \\
\text { activity }\end{array}$} & \multirow{2}{*}{ Chlorosis } & \multirow{2}{*}{$\begin{array}{c}\mathrm{LD}_{50} \\
\text { (mouse) }\end{array}$} & \multirow{2}{*}{$\begin{array}{c}\text { TLM } \\
\text { (killifish) }\end{array}$} & \multirow{2}{*}{$\begin{array}{c}\text { Granulomatous } \\
\text { change }\end{array}$} \\
\hline Acid (C-2) & Alcohol $(\alpha)$ & & & & & \\
\hline$(S)$ & $(S)$ & $3.5-4.0$ & $<1 / 16$ & 4 & 4 & - \\
\hline$(S)$ & $(R)$ & 0.3 & $1 / 2$ & - & $2-3$ & - \\
\hline$(S)$ & $(R S)$ & 2 & $1 / 4$ & $2-3$ & $2-3$ & - \\
\hline$(R)$ & $(S)$ & $<1 / 100$ & $<1 / 4$ & - & $<0.01$ & + \\
\hline$(R)$ & $(R)$ & $<1 / 100$ & 4 & - & $<0.01$ & - \\
\hline$(R S)$ & $(R S)$ & 1 & 1 & 1 & 1 & + \\
\hline
\end{tabular}

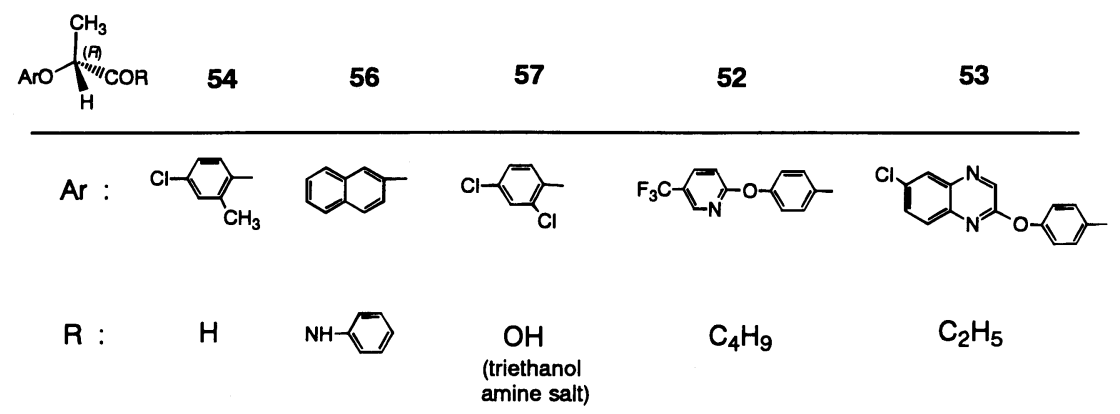

Fig. 6 Bioactive enantiomers of phenoxyacetic acid type herbicides $(\mathbf{5 2 - 5 4}, \mathbf{5 6})$ and plant growth regulator $(\mathbf{5 7})$.

イプとも, propionic acid の C-2 位は $(R)$-体が活性本体で あり，その鏡像体にはほとんど活性がなかった ${ }^{10 \sim 13)}$. 植物 生長調節剂として登録された dichlorprop $(57)$ も， $(R)$-体 のみが活性である ${ }^{14)}$. 生物活性をもつ鏡像体を Fig. 6 に示 す.

Inabenfide (45) は $(S)$-体にのみ植物生長調節作用があ $\eta{ }^{15)}$, Streptomyces sp. の生産する抗生物質を加水分解して 得られる glufosinate (58) の除草活性は, 天然型である $(S)-$ 体のみにある ${ }^{16)}$.

Hexythiazox (49)には二つの不斉中心があることから四 つの光学異性体が存在する. そのうち, 4-methyl と5chlorophenyl の trans 構造が活性発現に重要であることか ら，その両鏡像体が合成され，殺ダ二活性が調べられた。 その結果, $(4 R, 5 R)-(+)-49$ がラセミ体 $(4 R S, 5 R S)$ の約 2 倍の活性を示し，鏡像体には活性はなかった ${ }^{17)}$.

次に, 両鏡像体間の生物活性の差がそれほど大きくない 例を述べる．絶対配置 $(S)$ の levamisole (1) は，鏡像体やラ セミ体（tetramisole という）より数倍程度殺線虫活性が高 かった ${ }^{18)}$. しかし, マウスに对する急性毒性には差はなかっ た。また，有機リン系農薬の 10, 11, 13, 14, 21，22 な゙は， 鏡像体間に殺虫活性の差はそれほど大きくなかった，Sulprofos $(\mathbf{1 0})^{19)}$ と profenofos $(11)^{20)}$ はイエバエに対して $(R)_{\mathrm{p}}$ 体が $(S)_{\mathrm{p}}$-体より殺虫力は約 4 倍強かったが, acetylcholinesterase (AChE) に対しては $(S)$-体が強く阻害する という反対の結果であった．有機りン系農薬の絶対立体化 学と生物活性の関係について著者の総説がある ${ }^{21)}$.

殺菌剂の metalaxyl (29) は，(R)-体が $(S)$-体より in vivo

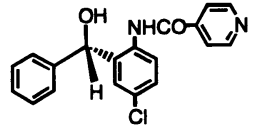

(S)-45

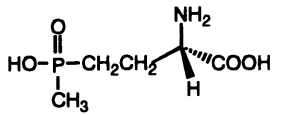

(S)-58<smiles>C[C@H]1[C@H](c2ccc(Cl)cc2)SC(=O)N1CC(=O)NC1CCCCC1</smiles>

$(4 R, 5 R)-49$<smiles>CCOP(=S)(S)OC1CCC(S)CC1</smiles>

$(R)_{\mathrm{p}}-(+)-10$

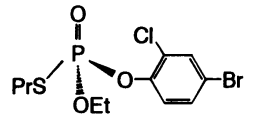

$(R)_{p}-(+)-11$
で3〜10 倍， in vitro で 1000 倍強かった ${ }^{22)}$. 他方，29 と同 様の2-アミノ酸誘導体である pefurazoate (40) は逆に, $(S)$-体が $(R)$-体よりエルゴステロール生合成阻害は 4 倍, イネバカ苗病菌に対して 30 倍強い活性を有していた ${ }^{23)}$ 。こ の場合, propionic acid および butyric acid の C-2 位の絶対 立体化学は逆となり，活性発現には分子の置換アミノ基の 構造も重要であることを示している. 除草剤 bromobutide $(46)$ は $(R)-$ - 体 $^{24)}$ に, 殺そ剤 warfarin $(68)$ は $(S)$-体 ${ }^{25)} に$ 強い 活性があった。また，フェノキシ酸系除草剤の cyhafopbutyl (8) と napropamide (50) は，ともに $(R)$-体が強い活性 を示したが, $(S)$-体にも活性が認められた ${ }^{26,27)}$.チャノコカ 
クモンハマキの性フェロモン（smalure）の 1 成分である 10-methyldodecyl acetate (72) は， $(R)$-体が $(S)$-体よりわず かに高いことが認められた ${ }^{28)}$ が，ラセミ体でも十分な活性 があったことから実用的にはラセミ体のままで使用されて いる。

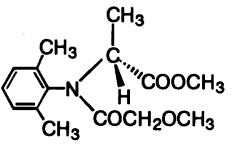

(P)-29

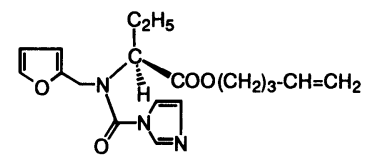

(S) -40

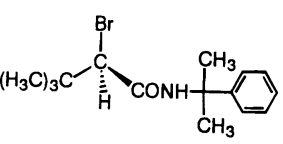

(R)-46<smiles>CCOCCN(CC)[C@H](C)Oc1cccc2ccccc12</smiles>

(R)-50

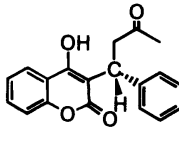

(S)-68<smiles>CC[C@H](C)CCC(C)=O</smiles>

$(R)-72$
両鏡像体間に生物活性の差がない例として，殺菌剂 triadimefon (30) がある ${ }^{29)}$. 分子中の不斉中心はカルボニル やトリアゾール基の $\alpha$ 位に位置することから, ラセミ化が 起こりやすく，そのことが活性に差のない理由と考えられ ている ${ }^{30)}$. しかし, カルボニル基の生物による水酸基への還 元反応が生体内活性化反応であるとの報告31)もある．生成 物 triadimenol (83) には, 新たに不斉炭素が生じて四つの光 学異性体が存在するようになる（Fig. 7) ので，それらを個 別に合成して活性を調べてみると, $(1 S, 2 R)-83$ がもっとも 強い殺菌作用を示し, 次いで $(1 R, 2 R),(1 R, 2 S),(1 S, 2 S)$ の順であった. 高い活性発現には, $(2 R)$ の絶対立体化学が 必須であった。

鏡像体間で生物活性が質的に異なる農薬には以下の例が ある。除草剂 metolachlor (28) は, 中心性キラリティー(不
斉元素によるキラリティー）と自由回転が妨げられること に起因する軸性キラリティー（アトロプ異性）をもつこと から, 四つの光学異性体が存在する. 混合物 (28) を光学分 割すると， $\left(\mathrm{a} R, 1^{\prime} S\right)$ がもっとも強い殺草作用を示し，(a $S$, $\left.1^{\prime} S\right),\left(\mathrm{a} S, 1^{\prime} R\right),\left(\mathrm{a} R, 1^{\prime} R\right)$ の順に活性が低下する ${ }^{32,33)}$. しか し，生物活性は軸性キラリティーよりも，中心性キラリ ティーに支配され，(1'S) の絶対配置をもつ 2 異性体の活性 が強かった。 また，28 は弱いながらも殺菌作用を有してお ク, Pythium ultinum に対する抗菌活性の強さは, 植物に対 する除草作用の強さと逆転した。

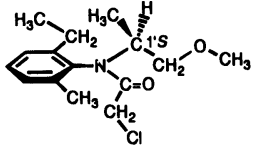

(aR,1'S)-28

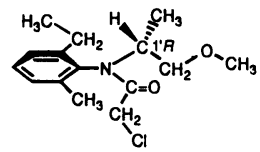

$\left(\mathrm{aS}, 1^{\prime} R\right)-28$

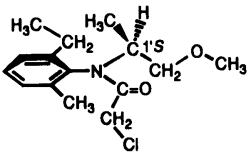

$\left(\mathrm{aS}, 1^{\prime} \mathrm{S}\right)-28$

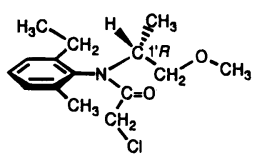

$\left(a R, 1^{\prime} R\right)-28$
トリアゾール系農薬には，殺菌作用を示すエルゴステ ロール生合成阻害剤と植物生長調節作用を示すジベレリン 生合成阻害剂がある. 植物生長調節剂 paclobutrazol (32) に は隣接する二つの不斉炭素が存在する. 32 を光学分割する 前に, erythro-ラセミ体 $(2 R S, 3 R S)$ と threo-ラセミ体 $(2 R S, 3 S R)$ が合成され，両者の生物活性が調べられたとこ ろ，植物生長調節作用および殺菌作用はともに erythro-ラ セミ体が強いことがわかった ${ }^{34)}$.そこで，これを光学分割し て得られた両鏡像体の生物活性を調べた結果，植物生長調 節作用は $(2 S, 3 S)-$-体が強く，殺菌作用は $(2 R, 3 R)$-体が強 かった.ところが, 活性の弱かった threo-ラセミ体を別途光 学分割して得られる鏡像体を調べると，植物生長調節作用 は $(2 R, 3 S)-$ 体が強く, 殺菌作用は $(2 S, 3 R)$-体が強かっ た $^{35)}$.このことから生物活性発現には,トリアゾール基のつ

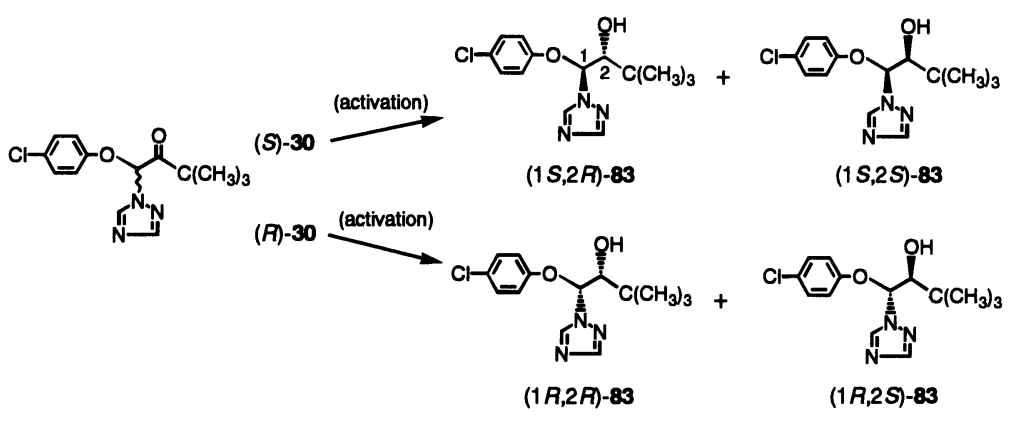

Fig. 7 Microbial reduction of triadimefon racemate (30) to four stereoisomers of triadimenol (83). 


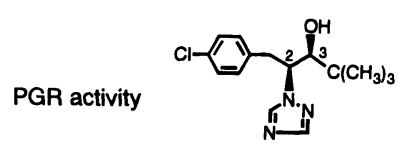

$(2 S, 3 S)-32$
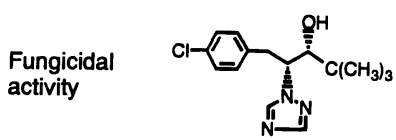

$(2 R, 3 R)-32$

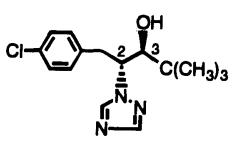

$(2 R, 3 S)-32$

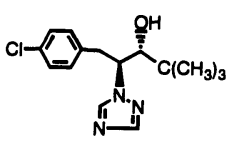

$(2 S, 3 R)-32$

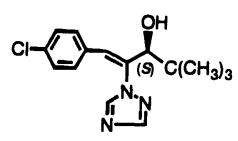

uniconazole-P (5)

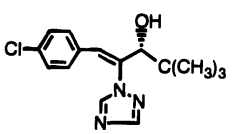

(R)-uniconazole

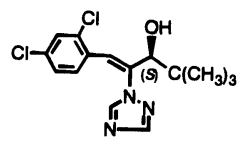

(S)-diniconazole [(S)-84]

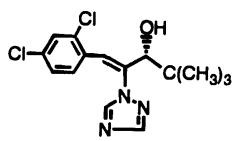

$(R)$-diniconazole $[(R)-84]$

Fig. 8 PGR and fungicidal activities of triazole compounds.

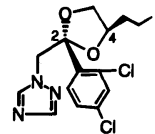

$(2 S, 4 S)-37$

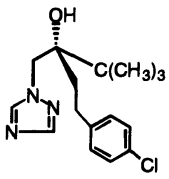

(S)-34

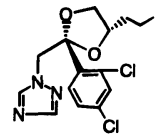

$(2 S, 4 R)-37$

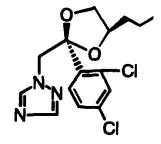

$(2 R, 4 S)-37$

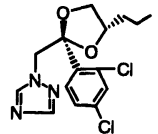

$(2 R, 4 R)-37$

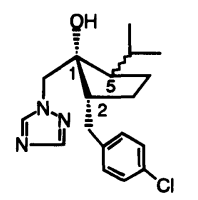

$(1 R, 2 R, 5 R S)-39$

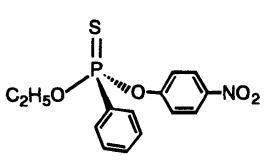

$(S)_{p}-17$
いた不斉炭素 C-2 位より，C-3 位の絶対立体化学が大きく 作用しているように思われる，C-2 位の不斉炭素に関して は, uniconazole-P (5) およびその類似化合物 diniconazole (84)においても，植物生長調節作用は $(S)$-体のほうが強 く，殺菌作用は $(R)$-体が強かったことと一致した（Fig. 8) ${ }^{36)}$. また，前述の triadimenol (83) において，(2R)-体が 強い殺菌作用を発現することとも一致した。

他方, propiconazole (37) は四つの光学異性体間に殺菌力 の強さの法則はなく，むしろ菌の種類により異なった。ま た, 37 には弱いながらも植物生長抑制作用があり， $(2 R)$ が $(2 S)$-体より活性が強かった ${ }^{37}$. 市販のラセミ体 (37) は，麦 類, 花き類に登録されている殺菌剤であるが, 散布にあたっ ては野菜にかからないように注意する必要がある。それは 薬害の恐れがある生長抑制作用を示寸鏡像体が含まれてい るためと考えられる. Tebuconazole (34) は $(S)$-体のほう が38), ipconazole (39) は $(1 R, 2 R, 5 R S)$-体が鏡像体 $(1 S$, $2 S, 5 R S)$ より強い殺菌活性を示した ${ }^{39}$. . しかし，これら化 合物の両鏡像体には植物生長調節作用があるという報告は ない. EPN (17) は両鏡像体間の殺虫作用には大きな差はな かったが，フェニルホスホン酸誘導体にみられる遅発性神 経毒が $(S)_{\mathrm{p}}-17$ にのみ認められている ${ }^{40)}$.

\section{Racemic switches とは}

これまで述べてきたように，キラル農薬を光学分割して 得られる両鏡像体（含ジアステレオマー）間には生物活性
がさまざまに異なる場合があり，とくに毒性や薬害等の使 用上不都合な性質も鏡像体間で異なる場合もあることがわ かってきた。すでにラセミ体として承認されているが，新 たに単一の鏡像体として再開発された光学活性な薬郕を医 薬品分野では “racemic switches” と呼んでいる，米国 FDA （1992 年 6 月）によれば，キラル医薬品においては，現在ラ セミ体で上市・市販されているものは，将来は単一の鏡像 体にしなければならない可能性が高く，今後開発されるも のは，ラセミ体でよいという十分な科学的根拠がある場合 を除き，最初から光学活性体で登録しなければならなくな るであろうとのことである ${ }^{3,41)}$. Racemic switchesによる利 点は，（1）副作用の軽減，（2）作用の分離，（3）投薬量の 改善，(4) 安全性の向上（潜在的毒性の軽減）などが考之 られる。

Racemic switches が行なわれた農薬には, esfenvalerate (6) がある.フェンバレレート (fenvalerate, 6 の光学異性体混 合物）は分子中に二つの不斉炭素を有していることから， 四つの光学異性体が存在する.フェンバレレートは 1983 年 に四つの光学異性体の混合物として登録され，単独ないし 有機リン殺虫剤との混合剂として，おもにアブラムシ類の 防除に用いられた。 ところが, 本剂を新葉展開期に散布す ると, 白化(黄化), 旧葉の落葉などの薬害を起こすことが あったそそこで，四つの光学異性体を合成し，それぞれの 生物活性を調べてみると, 酸部分およびアルコール部分(べ ンジル位) がともに $(S)$ 配位の絶対構造をもつ $(2 S, \alpha S)$-体 に殺虫活性があり，その $(2 R, \alpha R)$-鏡像体には強い白化性 を有することがわかった ${ }^{7,30)}$. さらに, $(2 R, \alpha S)$-体には, 亜 急性毒性の肉芽腫の発生が認められた $\left(\right.$ Table 4) ${ }^{42)}$. 各光学 異性体の殺虫力と哺乳動物や魚類への毒性とは正比例の関 係にあるが，人間 1 日当たりの捸取許容量 $(\mathrm{ADI})$ はフェン

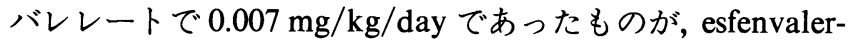
ate (6) では $0.02 \mathrm{mg} / \mathrm{kg} /$ day となり，摂取許容量が 3 倍に なった $((2 S, \alpha R)$-体には $200 \mathrm{ppm}$ の濃度でヨトウムシに 対して摂食忌避作用があるとの報告がある）。

また，ウニコナゾールは光学活性体 (uniconazole-P, 5) に切り替わったことにより, 生長抑制活性が 2 倍以上上昇 
し,成分含有量が半減する ${ }^{43)}$ こができ，そのうえ魚毒性も B 類から A 類に低くなった.

\section{光学活性化合物の特許について}

さて，光学活性化合物の特許を取得しょうとすると，ラ セミ化合物の既知特許とのからみで種々の問題が生じてく る。最初から光学活性体として特許申請された場合には問 題はないが，すでにラセミ化合物として特許が取得されて おり，その後単一の鏡像体に光学分割された化合物につい て,はたして特許取得ができるか否かは重要な問題である. わが国においては，1975 年特許に関する法改正により，物 質特許制度が導入され，化学物質自体の特許が認められる ようになった。化学物質の発明においても発明の進歩性, すなわち，構成の困難性が重視されるが，進歩性を有する 化学物質の発明として,

（1）化学構造が公知化学物質と類似していても，その化 学構造から予測できない特有な性質を有する化学物質の発 明,

（2）構造類似の公知化学物質から予測できる性質を有す る化学物質であっても，その性質の程度が著しく優れてい る化学物質の発明,

があげられる，すなわち，進歩性の判断にあたっては，発 明を構成することの難易だけでなく，その発明によっても たらされる効果の顕著性，意外性についても考慮されると 考えられる。ここで，ラセミ体と光学活性体の関係を化学 構造類似の化合物とみなされ得るとすると，ラセミ体を光 学活性体に代えたところ，毒性が著しく改善されたり，活 性が大きく上昇した場合には，特許性は十分にあるものと 考えられる。

実例を示すと，上述のフェンバレレートは，1976 年に四 つの光学異性体の混合物として特許権が発生した。その後, 単一の鏡像体として光学分割された esfenvalerate (6) に は，フェンバレレートに比較して 4 倍も高い殺虫活性があ ク，さらに薬害も改善された，その結果，esfenvalerateの有 する性質が著しく優れていることが認められ，1982 年に光 学活性体として特許保護された。また，トリアゾール系化 合物は殺菌作用と植物生長調節作用をあわせもつことが知 られている。 ウニコナゾールにも優れた矮化作用と弱いな がらも殺菌作用があることからラセミ体で特許が成立して いる. 光学分割された $(R)-(-)$-鏡像体には殺菌作用のみが あり，生育抑制作用がみられなくなったことから，薬剤を 誤って多量に施用した場合に起こる薬害を防止できるよう になり，1990 年殺菌剤として特許保護された.このように， ラセミ体で特許が認められている化合物でも, 光学活性体 にすると生物活性が著しく改善されたり，薬害等の副作用 が弱くなる，または消失する場合には特許性が認められる。

\section{光学活性体の合成法}

光学活性体を実際に調製する方法には，大別してラセミ 体 (racemate) を光学分割する方法と, 必要とする光学活性 体のみを直接得る方法の二つがある. 前者の光学分割方法 には，(1）優先晶出法，（2）ジアステレオマー法，（3）酵 素・微生物の利用，（4）キラル HPLCによる直接分離法な どがある．また，後者の希望する光学活性体を選択的に得 る方法には，(5) 光学活性化合物を出発物質として化学誘 導する方法，（6）不斉合成法，および（7）酵素·微生物の 代謝反応を利用する方法がある，不斉合成法は，目的化合 物を高い選択性をもって直接合成するので，もっとも有効 な方法であるようにみえるが，現時点においては，多くの 反応ステップと高価な光学活性試薬を必要とし, さらに分 離・精製に時間を要するなど，解決すべき問題も残されて いる．以下にキラル農薬の調製法についてこれらの方法を 解説しながら述べることにする。

\section{1. 優先晶出法}

優先晶出法とは，ラセミ体の飽和溶液からいずれか一方 の鏡像体を優先的に晶出させる方法である.ラセミ体には， ラセミ化合物 (racemic compound), ラセミ混合物 (conglomerate または racemic mixture) およびラセミ固溶体 (racemic solid solution）とがある.これらのうちでラセミ混合物の みが分別晶出することができる. ラセミ混合物の過飽和溶 液に希望する鏡像体の種晶を接種すると，その鏡像体が優 先的に結晶化する ${ }^{44)}$.

Fig. 9 に示す ( \pm$)$-cis-chrysanthemic acid [( \pm -cis-85] か ら誘導される $( \pm)$-dihydrochrysanthemolactone は，ラセミ 混合物として存在していることから，へキサン過飽和溶液 に(+)-体あるいは (一)-体の種晶接種により両鏡像体が得 られた4). 得られたラクトンの両鏡像体はそれぞれ酸処理 することによって，(+)-扔よび(一)-cis-85に導かれた。 こ れらを最強の殺虫力をもつ $(+)$-trans-chrysanthemic acid [(+)-trans-85] へ誘導する方法については後述する.

また，フェンバレレート（6の光学異性体混合物）の酸 部分である 3-methyl-2-(4-chlorophenyl)butanoic acid (86, CPIA) は，そのラセミ体 2 分子とアキラルなジエチルアミ ン 1 分子の塩溶液に，希望する 86 の鏡像体の種晶を加之， 優先晶析させる．残った溶液にもう一方の鏡像体の種晶を 入れれば，その鏡像体も結晶化する。この方法で $85 \%$ 以上 の光学純度の 86 の両鏡像体が交互に得られた (Fig. 10) ${ }^{45)}$.

\section{2. ジアステレオマー法}

本方法は，ラセミ化合物を光学活性の酸または塩基との 塩，またはジアステレオマーに化学誘導し，それらジアス テレオマー混合物の物理的性質の差を利用する光学分割法 である．ラセミ化合物に光学的に純粋な化合物（分割剤） を作用させて，一対の塩を形成するか，エステル，アミド 


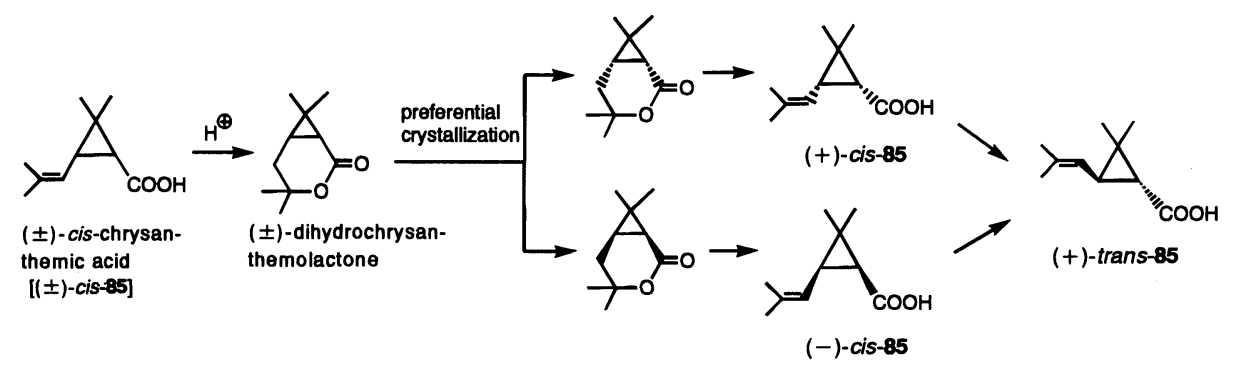

Fig. 9 Preferential crystallization of $( \pm)$-dihydrochrysanthemolactone.

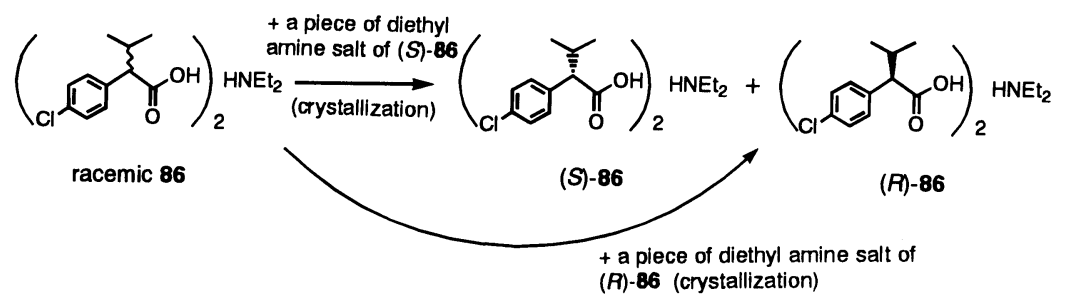

Fig. 10 Preferential crystallization of diethyl amine salt of racemic CPIA (86).

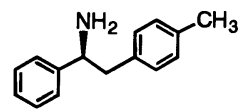

(S)-(+)-1-phenyl2-(4-tolyl)ethylamine

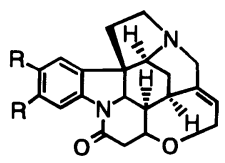

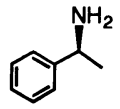

(S)-(-)- $\alpha$-phenethylamine

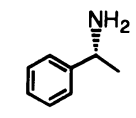

(R) $-(+)-\alpha-p h e n-$ ethylamine

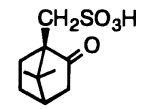

(-)-10-camphorsulfonic acid

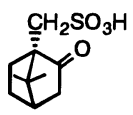

(+)-10-camphorsulfonic acid

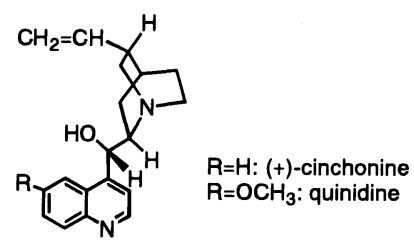

Fig. 11 Optically active acids and bases used for optical resolution as diastereomeric salts.

などの誘導体にする ${ }^{44)}$. 前者は Fig. 11 に示した各種分割剂 との塩の溶解度の差を利用した分別結晶法であり, 後者は ジアステレオマー誘導体を分別結晶法, またはクロマトグ ラフ法で分離する。単離された各ジアステレオマーを適切 な試薬によって化学分解し, それぞれの鏡像体を得る. シ アステレオマーの化学分解に際しては, ラセミ化が起こら ないことはもちろんのこと, 分割剤の回収率が高いことも 重要である。

分子内に塩基性基を有する tetramisole (1 のラセミ体) ${ }^{46)}$ や triadimefon (30) $)^{31}$ は，ラセミ体を(十)-または (一)-10camphorsulfonic acid とのジアステレオマー塩を，また酸性 基を有する warfarin $\left.(\mathbf{6 8})^{25}\right)$ は, quinidine との塩を形成さ せ，分別結晶法によって両鏡像体が得られた. ジアステレ オマー塩形成によってラセミ型原料酸を光学分割し, 目的 とする両鏡像体を得た例として, amiprofos-methyl (15) ${ }^{47)}$, butamifos (16) $)^{47)}$, EPN $(17)^{40,48)}$, metalaxy $(29)^{22)}$, bromobutide $(\mathbf{4 6})^{24)}$, napropamide $(\mathbf{5 0})^{27)}$, quizalofop-ethyl $\mathbf{( 5 3}^{49)}$, naproanilide $(\mathbf{5 6})^{11)}$, dichlorprop $(\mathbf{5 7})^{14)}$ がある.

他方, ジアステレオマー誘導体の形成法では, Casida ら は光学分割剤として L-proline Et esterを用いて sulprofos $(\mathbf{1 0})^{19)}$, profenofos $(\mathbf{1 1})^{20)}$ の両鏡像体を得ている (Fig. 12).

また, 10-methyldodecyl acetate (72) の原料酸である2-ethyl10-undecenoic acid は, $(S)-(-)$ - $\alpha$-phenethylamine との酸ア ミドを分別結晶法またはクロマト分離する方法が報告され ている (Fig. 13) ${ }^{50)}$.

2 個以上の不斉原子を有する化合物では, 4 個以上の光学 異性体が存在することから, 光学分割法も複雑となる。 二 つの不斉炭素が隣接した構造をもつ paclobutrazol (32)に は四つの光学異性体が存在する.これらの光学異性体のう ち, $(2 R, 3 R)$-および $(2 S, 3 S)-32$ は, $(2 R S, 3 R S)-32$ をそれ ぞれ(+)-，あるいは (-)-10-camphorsulfonic acid とのジア ステレオマー塩を形成することにより，また $(2 R, 3 S)$-お よび $(2 S, 3 R)-32$ は， $(2 R S, 3 S R)-32$ を $(1 S, 3 S)$-transchrysanthemic acid とのジアステレオマー誘導体に導き, 次 


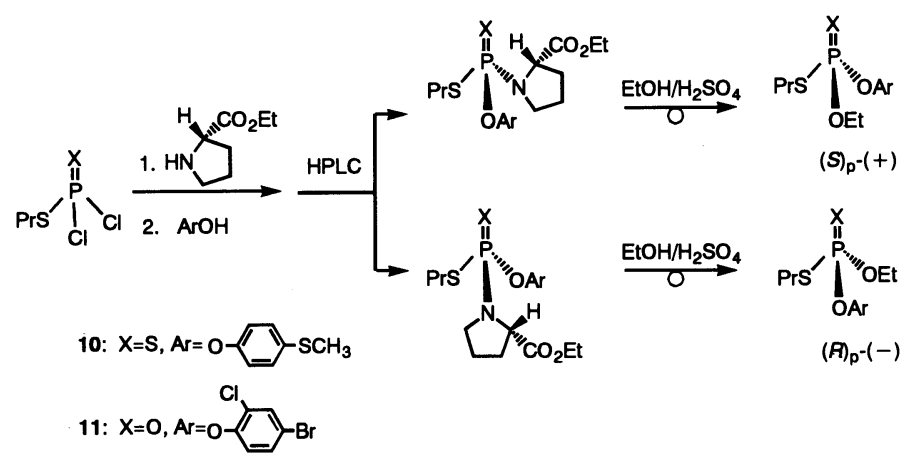

Fig. 12 Optical resolution of racemic sulprofos (10) and profenofos (11).

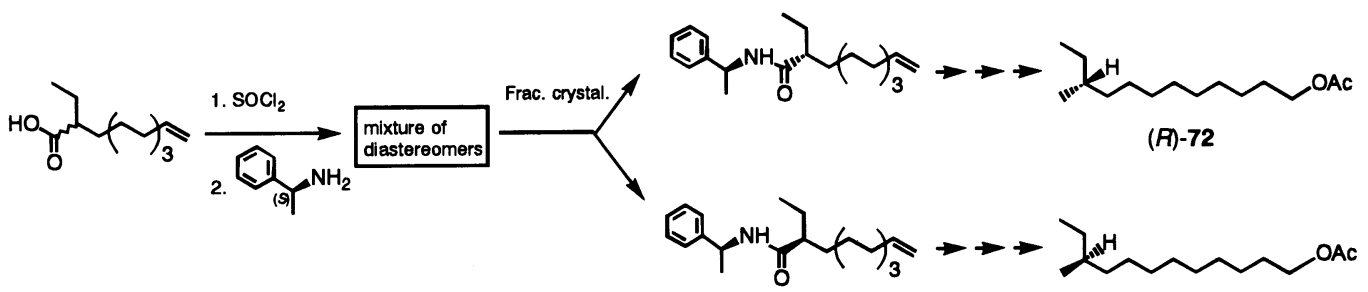

(S)-72

Fig. 13 Preparation of optical isomers of 10-methyldodecyl acetate (72).

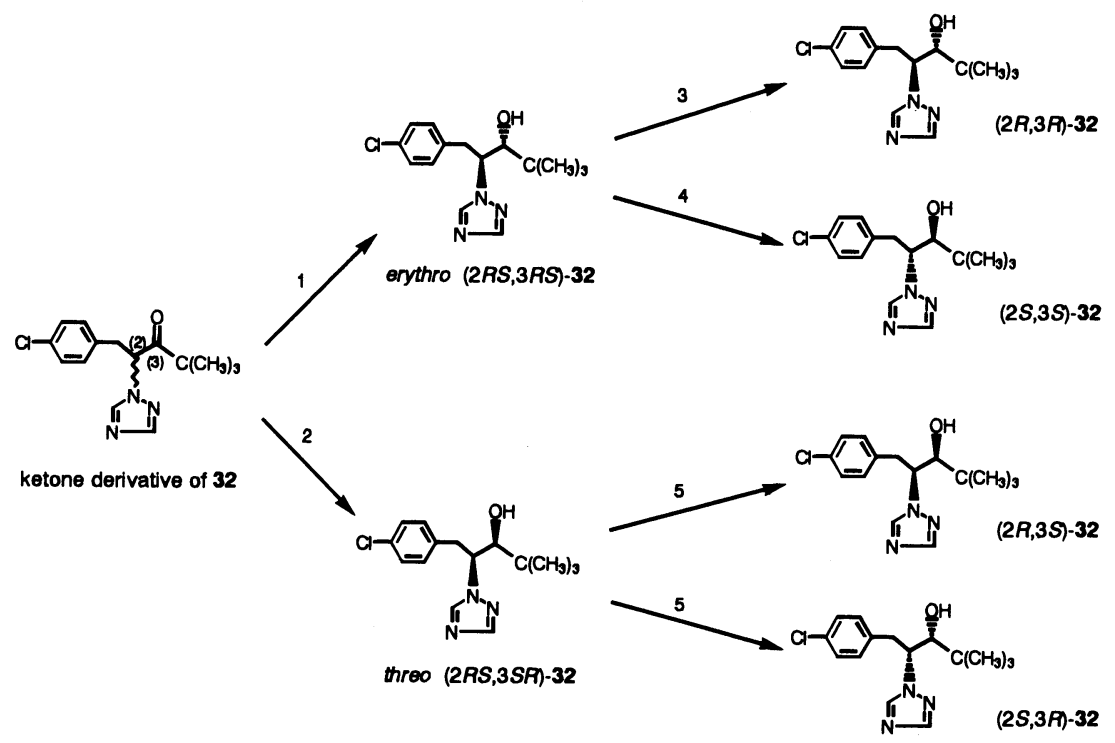

Fig. 14 Synthesis of four stereoisomers of paclobutrazol (32).

Reactions : $1, \mathrm{NaBH}_{4} ; 2, \mathrm{BuMgBr} ; 3$, (i) fractional crystallization of the diastereomeric salt with (+)-10-camphorsulfonic acid, (ii) $\mathrm{H}^{+}$; 4, (i) fractional crystallization of the diastereomeric salt with (-)-10-camphorsulfonic acid, (ii) $\mathrm{H}^{+}$; 5, (i) fractional crystallization of the diastereomer with $(1 S, 3 S)$-trans-chrysanthemic acid, (ii) $\mathrm{KOH}$ in EtOH.

いで光学分割することによって得られた（後者混合物は光 学活性 camphorsulfonic acid との塩からは分割できなかっ た). (2RS, 3RS)- および $(2 R S, 3 S R)-32$ は, ラセミ型 32 の ケトン基をそれぞれ $\mathrm{NaBH}_{4}$ あるいは $\mathrm{BuMgBr}$ 還元するこ とにより立体選択的に合成できた（Fig. 14） ${ }^{34,35) . ~}$

また, hexythiazox (49)にも四つの光学異性体が存在す る. Erythro 型 2-amino-1-(p-chlorophenyl)propanol から立 体選択的に誘導されるラセミ型 4, 5-trans-チアゾリドン体
のカルバモイル基の窒素を, 光学活性イソシアン酸化合物 とのジアステレオマー誘導体とし，カラムクロマトで分離 後, 49 の両鏡像体を合成した (Fig. 15) ${ }^{17)}$. Metolachlor (28) は軸性キラリティーをもつ唯一の農薬である.したがって, 不斉炭素とアトロプ異性によって四つの光学異性体が存在 する。それらはジアステレオマー塩およびジアステレオ マ一誘導体の光学分割法を組み合わせた光学活性体の合成 法が報告されている（Fig. 16） ${ }^{32,33) . ~}$ 


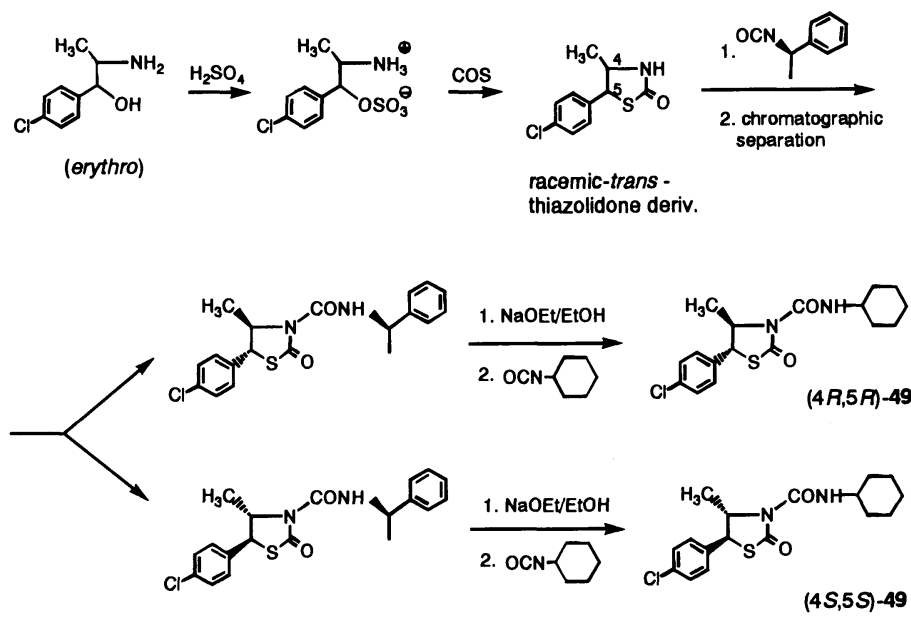

Fig. 15 Synthesis of the enantiomers of hexythiazox (49).

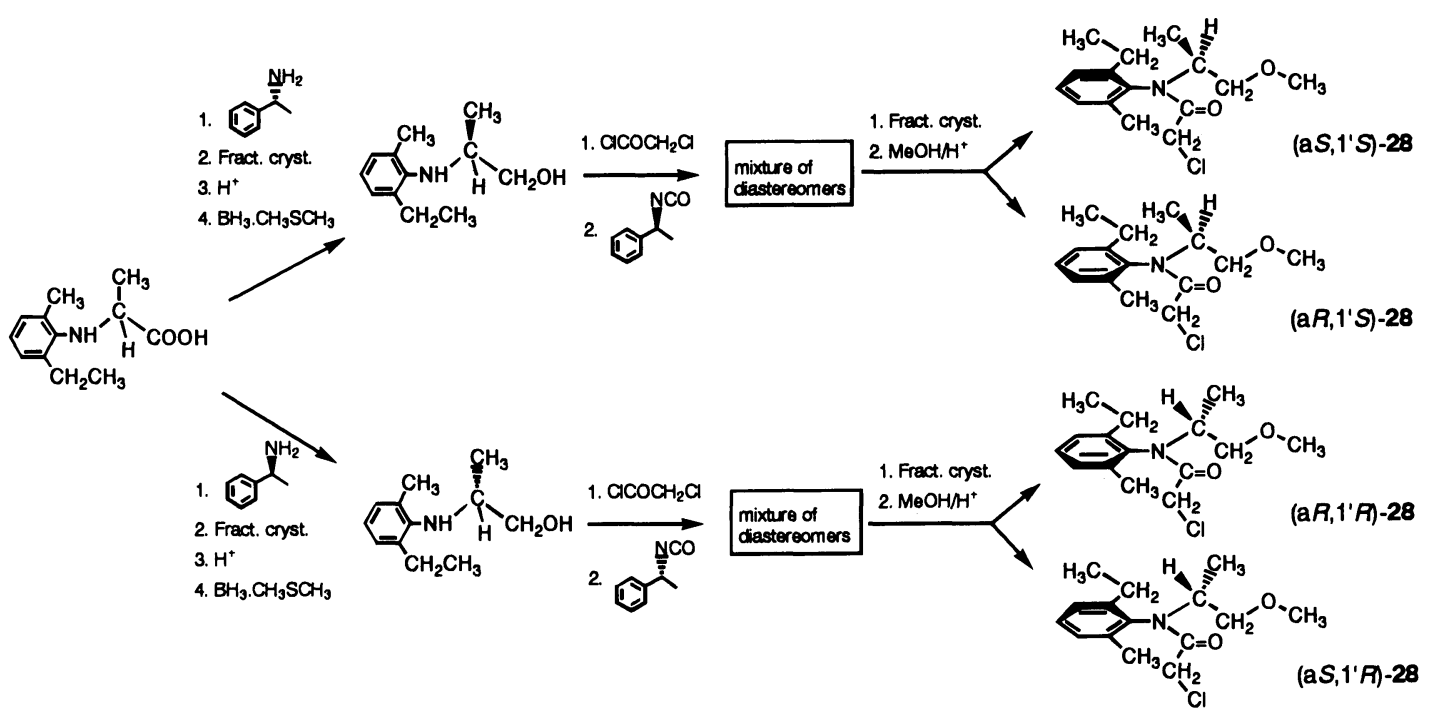

Fig. 16 Synthesis of four stereoisomers of metolachlor (28).
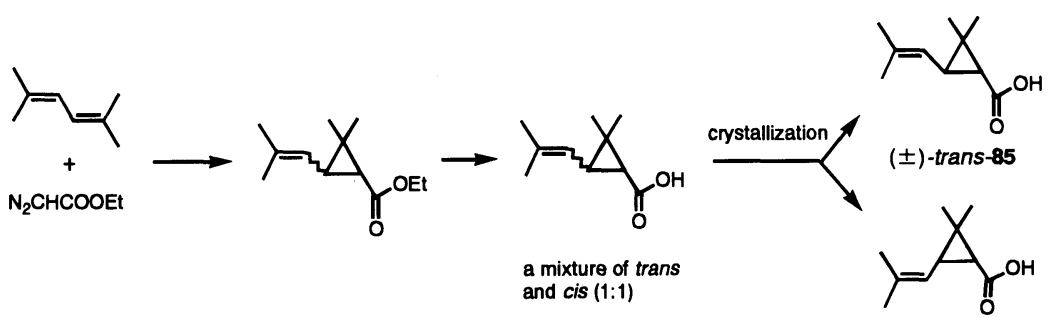

(士)-cis-85

Fig. 17 Preparation of racemic trans-and cis-isomers of chrysanthemic acid (85).

光学活性ピレスロイド系殺虫剤の合成は, 最初は菊酸部 分とアルコール部分が独立して合成された ${ }^{51)}$. 酸部分の合 成法については, allethrin (73) の酸部分である chrysanthemic acid (85) は Fig. 17 に示すように，ジアゾ酢酸エチル エステルとジエンとの反応で得られる $( \pm)-85$ の trans-体 と cis-体の混合物を，分別結晶することによって純粋な trans-体とcis-体が得られた。それぞれをジアステレオ
マー塩として分別結晶法で四つの光学異性体に分割された (Fig. 18).また，工業的な製法としてラセミ型 85 の trans ${ }^{-}$ 体と cis-体の混合物を分離することなく，(+)-trans と (+)-cis の混合物 85 を高収率かつ回収再利用できるアミン として (+)-1-phenyl-2-(p-tolyl)ethylamine (Fig. 11) が開発 された．殺虫活性は trans-85 が強いことから，選択的に合 成する方法も報告されている（Fig. 19)。Tralomethrin (4) 
の酸部分は Fig. 20 に示すように trans-85 の両鏡像体から ラセミ化を伴わない反応によってそれぞれ化学誘導され $ろ^{6)}$. ラセミ型 CPIA (86) は, 光学活性 $\alpha$-phenethylamine $の$
$( \pm$

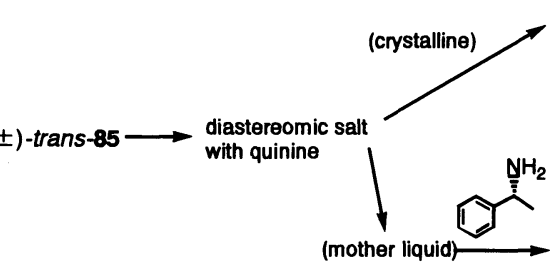

(士)-cis-85

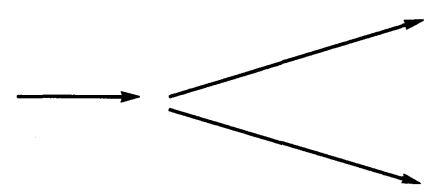

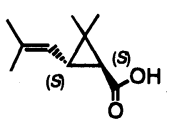

(-)-trans-85

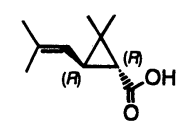

(+)-trans-85

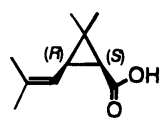

(-) -cis-85

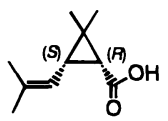

$(+)-c i s-85$
Fig. 18 Optical resolution of trans- and cis-isomers of chrysanthemic acid (85).
両鏡像体とのジアステレオマー塩として容易に光学分割さ れる8).

次に，アルコール部分については， allethrolon (87) は無 水フタル酸とのハーフエステル酸の光学活性アミンとのジ アステレオマー塩から得られる(Fig. 21)。 Tralomethrin (4) や fenvalerate (6 の光学異性体混合物) のアルコール部分の 光学異性体のユニークな合成法として，(士)- $\alpha$-hydroxy- $\alpha$ (3-phenoxyphenyl)acetonitrile (88) を光学活性 85 や (S)-86 とのジアステレオマーに誘導すると，殺虫活性の強いジア ステレオマーが容易に結晶化した (Fig. 22) ${ }^{51)}$.

\section{3. 酵素・微生物の利用}

この方法は，酵素や微生物がもっている高度の鏡像体区 別反応（基質特異性）を利用して，ラセミ体を光学分割す る方法である。一般に酵素や微生物の利用は, 経済性に優 れている点があげられる.反応は通常バッファー溶液中で, 温度 $20 \sim 30^{\circ} \mathrm{C}$ で行なわれる. しかも反応は基質特異的で, 光学純度 (ee) ほぼ $100 \%$ で, 一方の鏡像体のみが得られる. 欠点としては, 反応がゆっくりと進行し, 基質濃度も有機 反応に比べ希薄であり，大きな容器を必要とする．さらに， 生成物の単離に時間と労力を必要とする. Allethrin (73)の アルコール部分 allethrolon (87)の酢酸エステルは, Bacil-

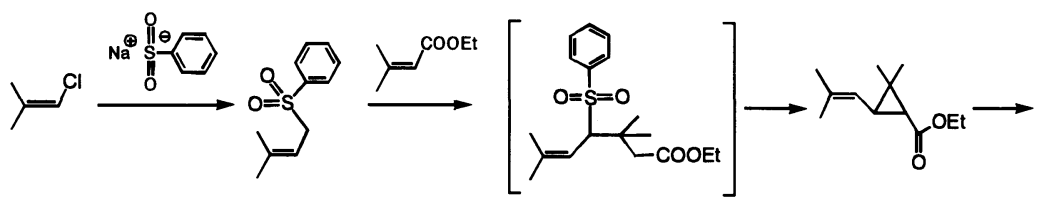

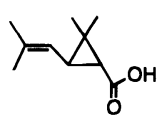

(士)-trans-85
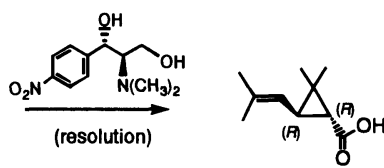

(+)-trans-85 (crystalline)

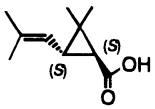

(-)-trans-85

(filtrate)

Fig. 19 Stereoselective synthesis and chiral resolution of trans-isomer of chrysanthemic acid (85).

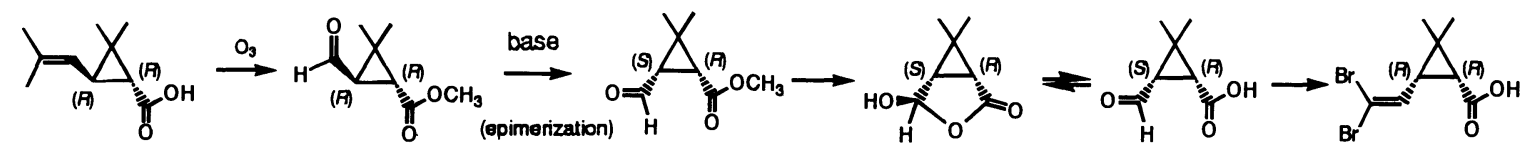

$(+)-$ trans-85
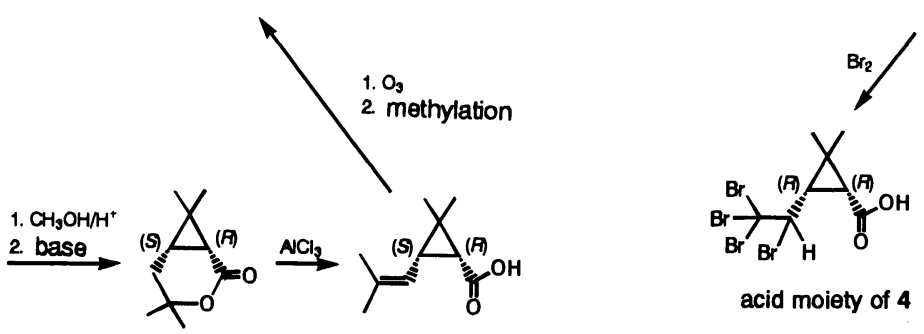

$(+)-c i s-85$

Fig. 20 Chemical derivatization of (+)- and (-)-trans-chrysanthemic acids (85) to the acid moiety of tralomethrin (4). 


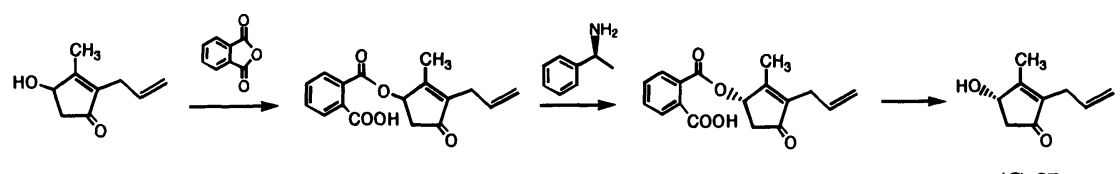

racemic 87

(S)-87

Fig. 21 Resolution of racemic allethrolon $(87)$ to the $(S)-87$.

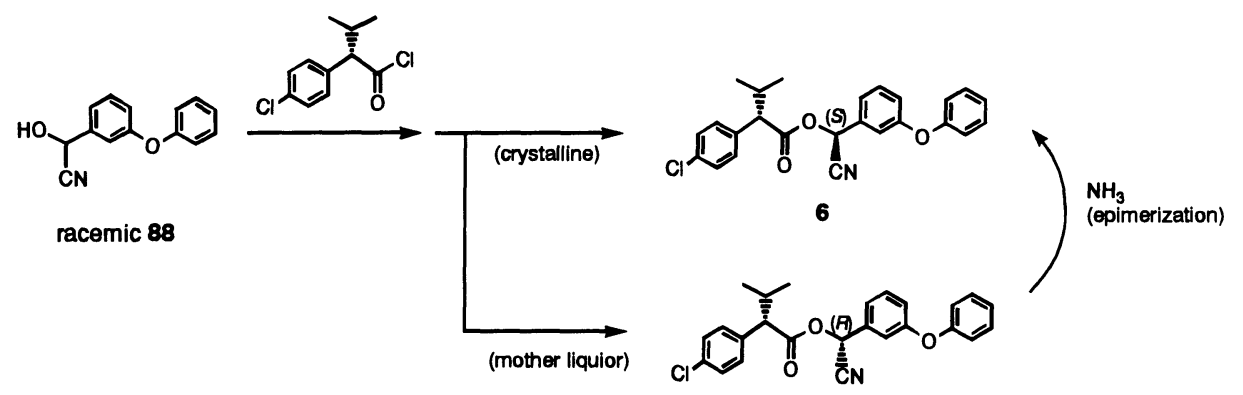

Fig. 22 Preparation of esfenvalerate (6) without resolution of the racemic alcohol moiety (88).

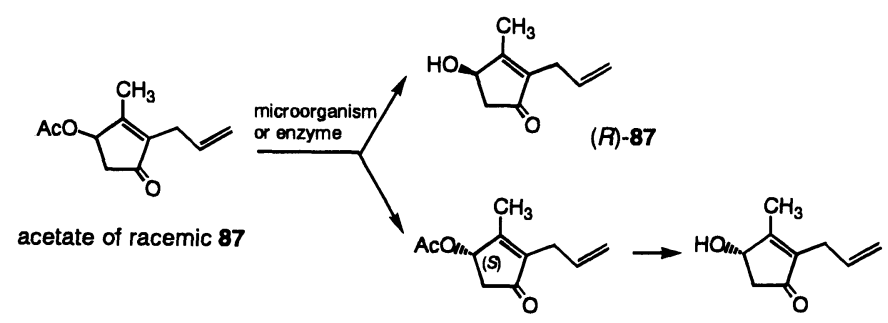

$(S)-87$

Fig. 23 Asymmetric enzymatic hydrolysis of racemic allethrolon acetate to $(R)$-allethrolon $[(R)-87]$.

lus subtilis var. Niger または Trichoderma sp. 由来の酵素に よって不斉加水分解を受けて，(R)-87 が選択的に得られ た. 回収された未反応の酢酸エステルからはアルカリ加水 分解によって $(S)$-体が得られた (Fig. 23) ${ }^{52)}$.

\section{4. キラル HPLC による分離法}

HPLC 用のキラルカラムの開発はめざましく，多種類の カラムが市販されており，かなりの化合物の分離が可能と なった. キラル HPLC 法の利点は, ジアステレオマー化す ることなく，化合物そのものの直接分離が可能で，かつ高 い光学純度 $(100 \%$ ee 達成可能) の両鏡像体が得られること である.しかし，キラル充填剤が高価であること，操作上 溶質の濃度を低くする必要があるため多量の溶媒が必要で あり，そのため装置も大規模となるなどの問題点がある. 生物試験や代謝実験用として少量サンプルのための光学分 割例には, acephate $(\mathbf{1 3})^{53)}$, isofenphos $(\mathbf{1 4})^{54,55)}$, ipconazole (39) $)^{39)}$ が報告されている.

最近, 疑似移動床 (simulated moving bed, SMB) 式 HPLC 法が開発されて, 工業規模の光学分割も可能となってき た ${ }^{56)}$. 本方法は, 8〜12 個またはそれ以上のキラルカラムを 直列につないで使用する方法で, 最終力ラムの出口が最初 のカラムに戻るリサイクルポンプをもつ循環方式である.
2 成分の分離に適していることから, ラセミ化合物の光学 分割に応用されるようになった. SMB 法を単力ラム法と比 較すると, 一般に処理能力 (productivity) で2〜10 倍, 溶 媒使用量は数分の 1 数 10 分の 1 程度と報告されている. 農薬の例ではないが, 医薬品の合成原料である $(R)-3-$ chloro-1-phenylpropanol のラセミ体を光学分割するに要す るコストは, 年間 10 トン分離するのに 700 ドル $/ \mathrm{kg}$ を要 し, 不要の $(S)$-体はラセミ化後, リサイクルされる ${ }^{3)}$. 経済 的スケールは年間 40 トンと報告されている. 本方法は今後 農薬の分離にも応用されるものと考之られる. SMB 法の原 理については文献年)を参照されたい.

\section{5. 立体変換（ラセミ化）技術}

以上，ラセミ体からの光学分割法について述べたが，も し一方の鏡像体のみが必要な場合には, 他方の鏡像体は不 要となる.この不要となった鏡像体を化学反応によってラ セミ体に戻して，再び光学分割することができれば，不要 の鏡像体を捨てることなく，必要とする鏡像体のみを得る ことができる.このことは，実用化段階では非常に重要な ことである. Tetramisole (1のラセミ体)の光学分割の結果

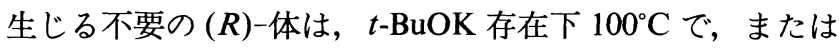
DMSO 中 $\mathrm{NaNH}_{2}$ で容易にラセミ化される ${ }^{46)}$. 光学活性 


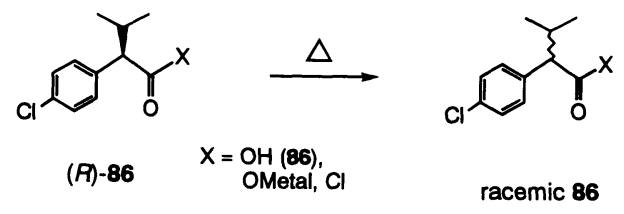

Fig. 24 Pyrolytic racemization of $(R)$-CPIA (86).

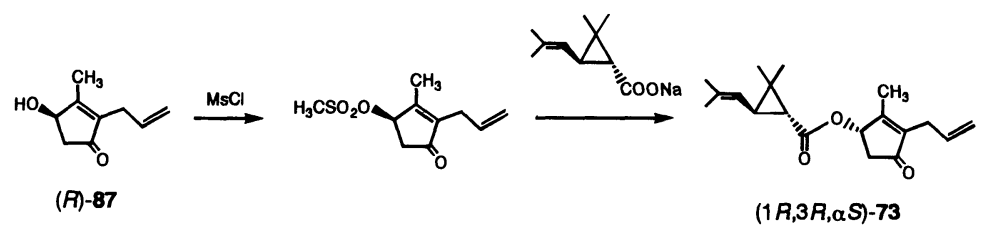

Fig. 25 Esterification of $(R)$-allethrolon $[(R)-87]$ with $(+)$-transchrysanthemic acid to $(1 R, 3 R, \alpha S)$-allethrin (73).
CPIA (86) は, そのままで $150^{\circ} \mathrm{C}$ 以上に加熱, 金属塩にして 120 200 $\mathrm{C}$ に加熱, または酸クロライドに変換して $80^{\circ} \mathrm{C}$ 以上に加熱のいずれかでほぼ定量的にラセミ化が起こる (Fig. 24) ${ }^{51}$.

この場合, ラセミ化を行なっても生成物の半分は不要な 鏡像体として残るため, さらにラセミ化を続けなければな らない。もし，希望しない鏡像体をある操作によって希望 する鏡像体に変換することができれば望ましい，殺虫活性 の弱い $(R)$-allethrolon $(87)$ から $(S)$-体への変換方法が報 告されている (Fig. 25) ${ }^{51}$. また, 殺虫活性のない $(2 S, \alpha R)-6$ は, アンモニア中で容易にエピ化を起こし, 活性の強い $(2 S, \alpha S)$-体が得られる (Fig. 22) ${ }^{51)}$.

もっともよく研究されている chrysanthemic acid (85)に ついては, $(1 R, 3 R)$-trans-体の殺虫活性が最強であるので, 他の三つの異性体を $(1 R, 3 R)$-trans-体に立体変換するた めの化学反応が開発されている (Fig. 26) ${ }^{58)}$. すなわち, (一)-cis-体のC-1-エピ化は, 220～250 ${ }^{\circ} \mathrm{C}$ に加熱するか, エ ステル化後触媒量の塩基を無溶媒中で作用させると, およ そ90\%の収率で得られた. (+)-cis-体は, パラジウム錯体触 媒を用いるか，エステル化物にルイス酸を作用させると立 体選択的にC-3 位のエピ化が起こり, 90\%以上の収率で (+)-trans-体が得られた。(-)-trans-体は直接過酸化物の 存在化, 三臭化ホウ素, 三臭化アルミニウムなどと反応さ せると,ラセミ化が進行した. また，(一)-trans-体の酸塩化 物をルイス酸で処理すると円滑なラセミ化が起こった.

\section{6. 光学活性化合物から光学活性農薬への化学誘導法}

容易に入手できる光学活性化合物の両鏡像体から化学変 換反応によって目的とする農薬の両鏡像体が合成されてい る. ピレスロイド系殺虫剂の酸部分でもっとも殺虫力の強

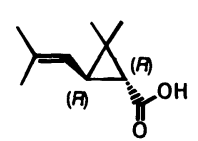

(+)-trans-85

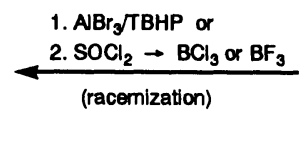

(racemization)

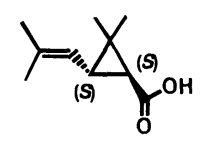

(-)-trans-85

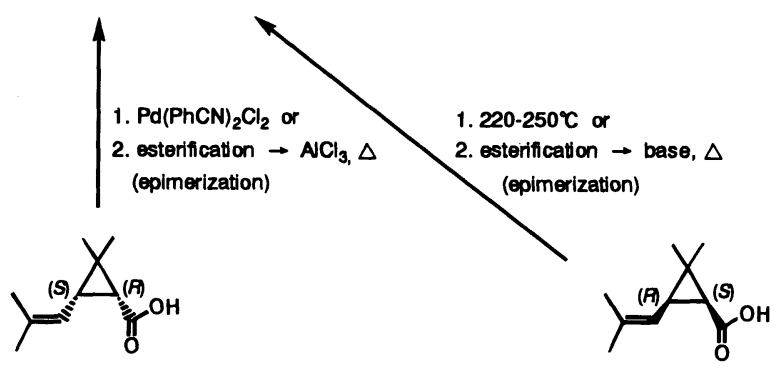

$(+)-$ cis-85

Fig. 26 Isomerization of three stereoisomers of chrysanthemic acid (85) to the (+)-trans-85.

い(1R,3R)-trans-85 は, (+)-3-カレン, (+)- $\alpha$-ピネンや $(+)$-リモネなどの天然物からの化学誘導が報告され た $^{51)}$. Malathion (21) ${ }^{59}$ および phenthoate (22) ${ }^{60)}$ の両鏡像体 が，それぞれ malic acid および mandelic acid の両鏡像体か ら不斉炭素の反転を伴う化学反応によって合成された (Figs. 27, 28). Tetramisole (1のラセミ体) ${ }^{18)}$, pefurazoate $(\mathbf{4 0})^{23)}, 10$-methyldodecyl acetate $(\mathbf{7 2})^{61)} の$ 両鏡像体も Figs. 29〜31に示した方法で化学合成された。

Propiconazole (37) は，(S)-2-aminobutanoic acid から誘 導される $(S)$-1, 2-pentanediol (89) と acetophenone 誘導体 との反応で生成するケタール体に，1，2，4-triazoleを作用さ せて得られるジアステレオマーをカラムクロマト分離し て, $(2 R, 4 S)$ - および $(2 S, 4 S)-37$ が得られた. 同様の反応で

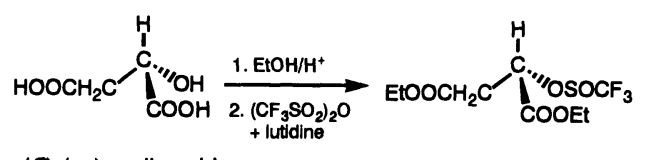

(S)-(-)-malic acid

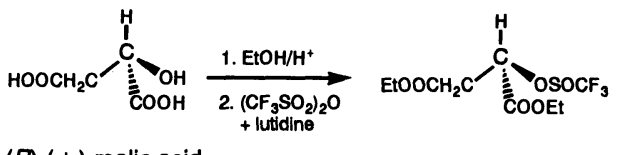

$(\boldsymbol{R})-(+)$-malic acid

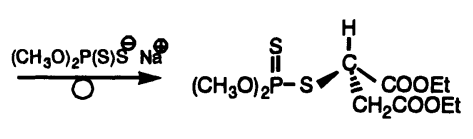

$(R)-(+)-21$

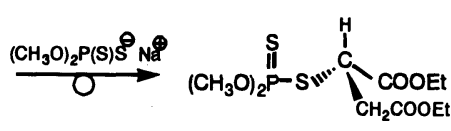

(S)-(-)-21

Fig. 27 Preparation of $(R)-(+)$ and $(S)-(-)$ enantiomers of malathion (21). 
(R)-2-aminobutanoic acid から $(2 R, 4 R)$-および $(2 S, 4 R)$ 37 が得られた (Fig. 32) 62).

Tebuconazole (34) の両鏡像体は, (+)-pulegone から 2 環 性の oxathiane 化合物を経由し, Fig. 33 に示寸ルートで合 成された ${ }^{63)}$. すなわち, ルートAにおけるグリニヤール試 薬の付加反応は, 高い立体選択性で進行し, $(S)$-34 の光学 純度は 95\% ee であった. 他方, ルート B の立体選択性は低 く $(48 \% \mathrm{ee})$, カラムクロマトで分離して得た光学的に純粋 な diastereomer-B から $(R)-34$ が得られている.

\section{7. 不斉合成法}

本方法は, 目的とする光学活性化合物を不斉反応を利用 してアキラル化合物から直接合成する有効な方法である. 前述の propiconazole (37) の両鏡像体の合成のキーステッ
プは，光学活性 1, 2-pentanediol (89)の合成である.その光 学活性化合物からの合成は規模が小さく, 実用化が困難な ことから, Chiba-Geigy 社は大規模な合成法として,アキラ ル 1-hydroxypentane-2-one の不斉還元法を開発した（Fig. 34a) ${ }^{37)}$ とれによると触媒として $\mathrm{RuCl}_{2}[(S)$-BINAP $]$ を用 いると, 95\% ee の $(S)-89$ が, $\mathrm{RuCl}_{2}[(R)$-BINAP $] て ゙ は ~(R)-$ 89 がほぼ定量的に得られた。 Aratani ら ${ }^{64)}$ は $(1 R, 3 R)$ trans-85 のエステルを, キラルシッフ塩基触媒を用いた不 斉合成法で $90 \%$ ee 以上で得ている (Fig. 35)。この場合, 工 業的な合成法の問題点として, 不斉触媒のコスト高の原因 となる回収率と再使用の可否がある.

植物生長調節剂 uniconazole-P (5) は，アキラルなケトン 体を $(S)$-アミノアルコール誘導体の存在下, $\mathrm{NaBH}_{4}$ 還元

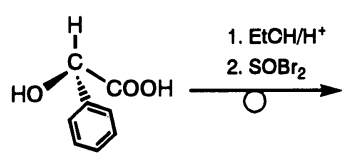

$(R)-(-)$-mandelic acid

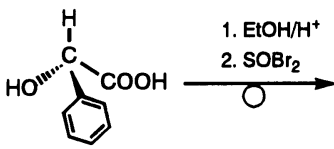

(S)-(+)-mandelic acid

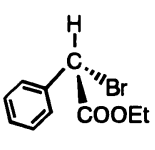

$\underset{\mathrm{O}}{\stackrel{\left(\mathrm{CH}_{3} \mathrm{O}\right)_{2} \mathrm{P}(\mathrm{S})}{\ominus} \mathrm{S}^{\ominus} \mathrm{N}}$<smiles>CCOC(=O)[C@H](CSP(O)(=S)OC)c1ccccc1</smiles>

$(R)-(-)-22$

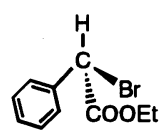

$\underset{\mathrm{O}}{\stackrel{\left(\mathrm{CH}_{3} \mathrm{O}\right)_{2} \mathrm{P}(\mathrm{S}) \mathrm{S}^{\ominus} \mathrm{N}}{\longrightarrow}}$<smiles>C=CC(C(=O)OCC)C(=O)SP(=S)(OC)OC</smiles>

(S)-(+)-22

Fig. 28 Preparation of $(R)-(-)$ and $(S)-(+)$ enantiomers of phenthoate (22).

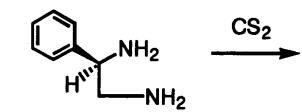

(S)-(+)-phenylenediamine

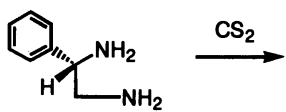

(R)-(-)-phenylenediamine

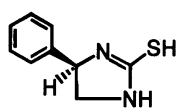

$\mathrm{NH}$
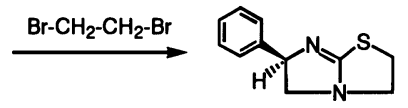

1

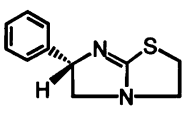

enantiomer of 1

Fig. 29 Preparation of levamisole (1) and its antipode.

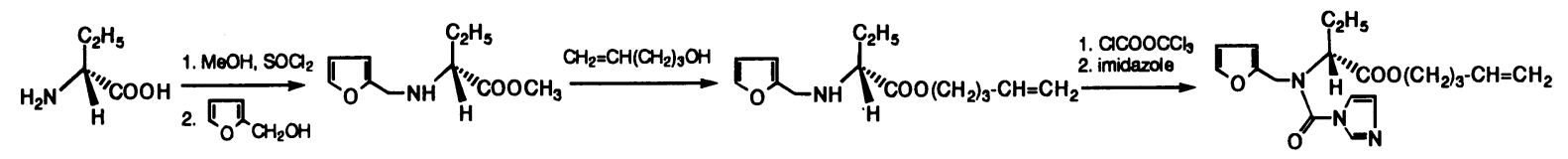

(R)-(-)-2-aminobutanoic acid

$(R)-(+)-40$

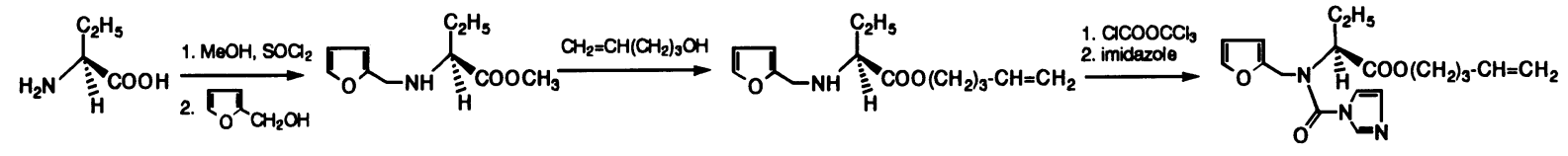

(S)-(+)-2-aminobutanoic acid

$(S)-(-)-40$

Fig. 30 Preparation of $(R)-(+)$ and $(S)-(-)$ enantiomers of pefurazoate $(40)$. 


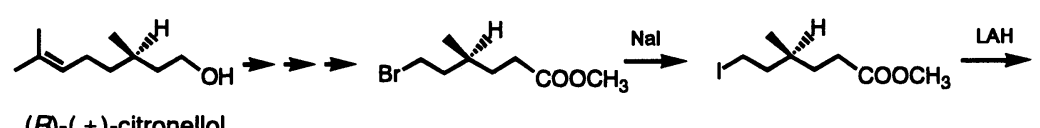

$(R)-(+)$-citronellol

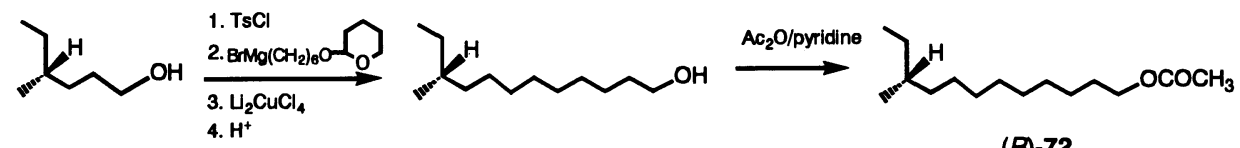

(R)-72

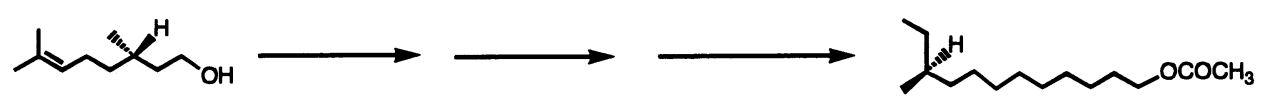

(S)-(-)-citronellol

(S)-72

Fig. 31 Synthesis of $(R)$ and $(S)$ enantiomers of 10-methyldodecyl acetate (72).
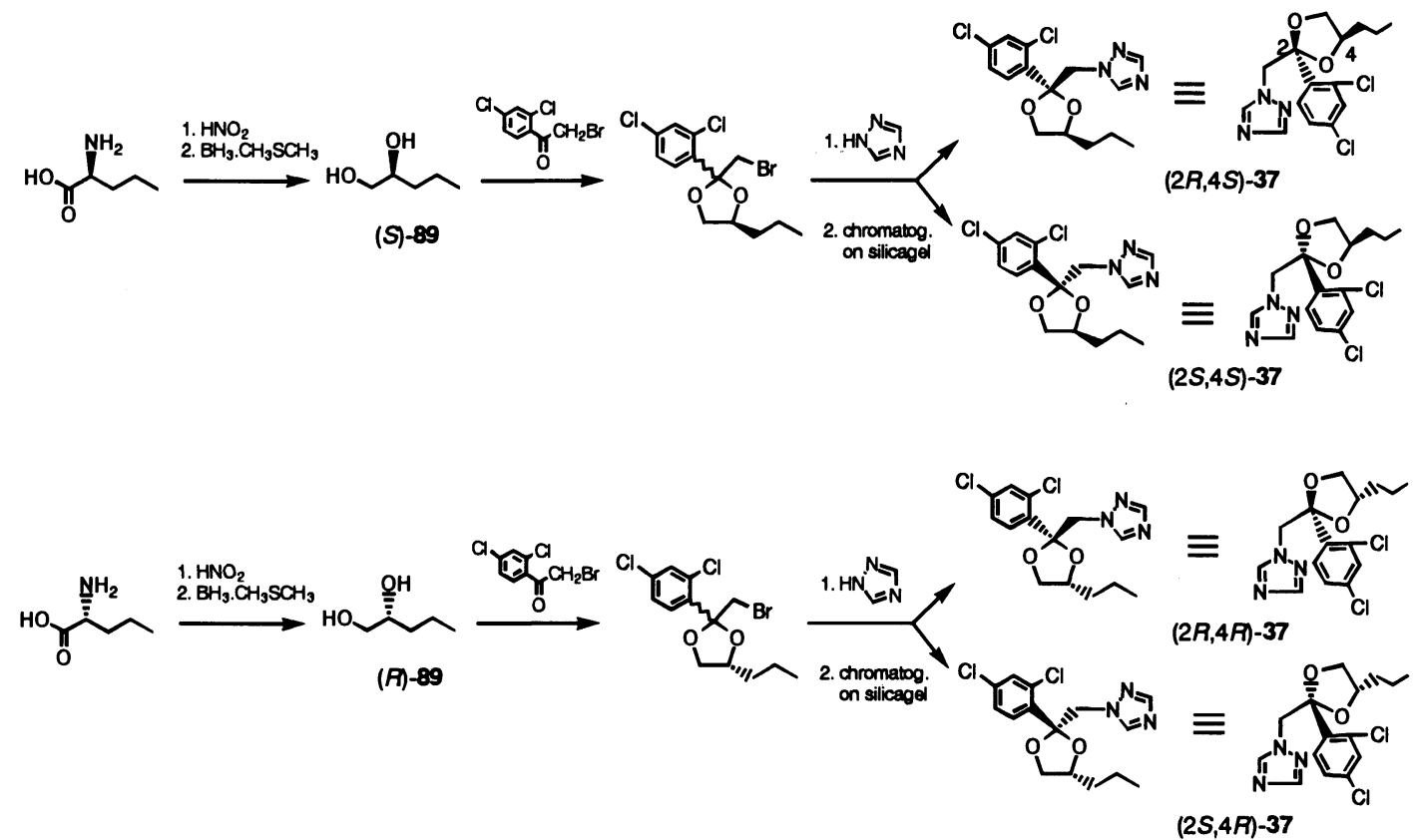

Fig. 32 Synthesis of four stereoisomers of propiconazole (37).

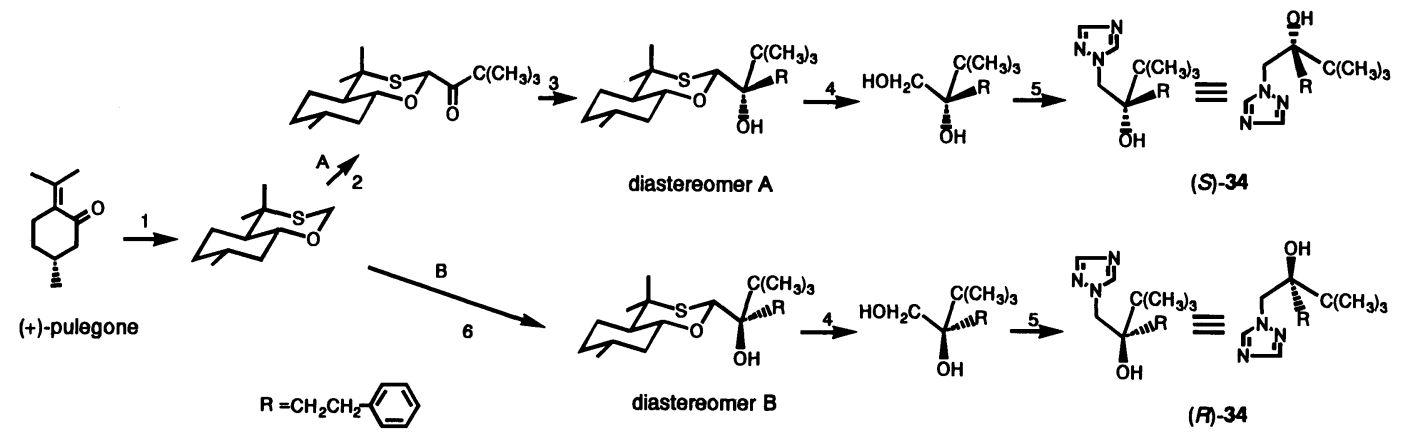

Fig. 33 Synthesis of $(S)$ and $(R)$ enantiomers of tebuconazole (34) from (+)-pulegone.

Reactions : 1, (i) $\mathrm{PhCH}_{2} \mathrm{SH}$, (ii) $\mathrm{Na}, \mathrm{NH}_{3}$, (iii) paraformaldehyde ; 2, (i) $\mathrm{BuLi}$, (ii) EtCHO, (iii) $\mathrm{NH}_{4} \mathrm{Cl} / \mathrm{H}_{2} \mathrm{O}$, (iv) $\mathrm{DMSO} / \mathrm{THAA}$; 3, $\mathrm{R}-\mathrm{MgBr}$; 4, (i) $\mathrm{NCS} / \mathrm{AgNO}_{3}$, (ii) $\mathrm{LiAIH}_{4}$; 5, (i) $\mathrm{MsCl}$, (ii) $1 H$-1, 2, 4-triazole ; 6, (i) BuLi, (ii) $t$-BuCOR, (iii) column chromatography. 
して高い光学収率で得ている (Fig. 36) ${ }^{65)}$. また，その $(R)-$

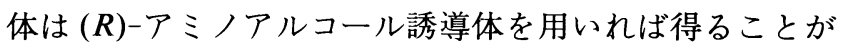
できる. 同様にして, 除草活性のある glufosinate (58)の $(S)$-体は Fig. 37 に示す方法で得られた ${ }^{16)}$.

a) asymmetric hydrogenation

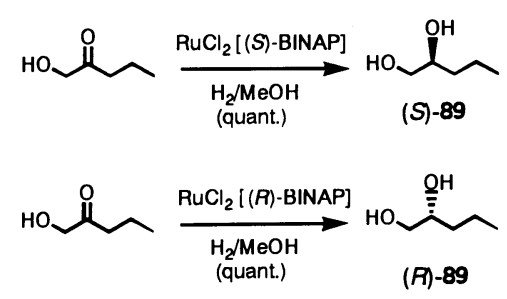

b) enzymatic reduction by L- and D-lactate dehydrogenase

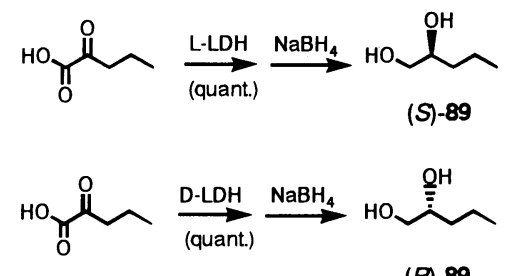

(R)-89

Fig. 34 Key enantioselective reactions for preparation of $(S)$ and $(R)$ enantiomers of 89.

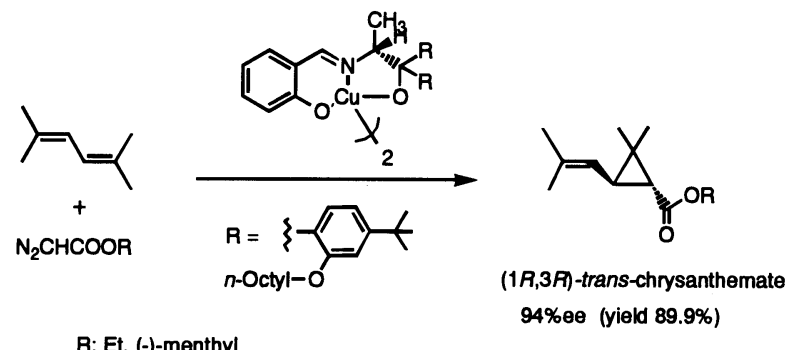

R: Et, (-)-menthyl

Fig. 35 Asymmetric synthesis of $(1 R, 3 R)$-trans-chrysanthemate.

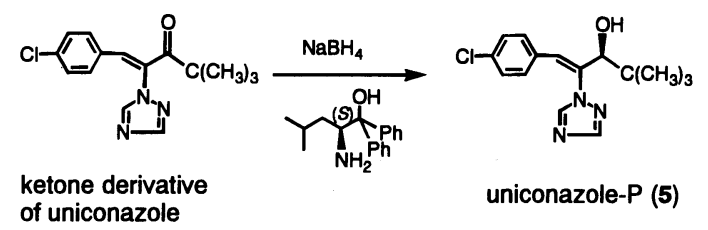

Fig. 36 Asymmetric reduction of a ketone derivative of uniconazole.
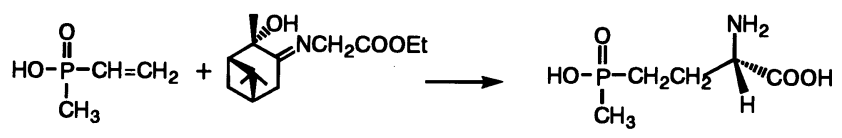

(S)-58

Fig. 37 Asymmetric synthesis of $(S)$-glufosinate (58).

\section{8. 酵素・微生物利用による不斉合成法}

$\mathrm{L}$-乳酸脱水素酵素を使った $\alpha$-ケト酸のアルコールへの 立体選択的還元は，よく知られた方法である。本法は, propiconazole (37) の合成原料である 89 の両鏡像体の合成 にも応用され,アキラルな 2-oxopentanoic acid を L-乳酸脱 水素酵素によって定量的に $(S)$-2-hydroxypentanoic acid に 還元し, さらに $\mathrm{NaBH}_{4}$ で還元して $99 \%$ ee の $(S)-89$ が高収 率で得られた ${ }^{37)}$. 同様にして, D-乳酸脱水素酵素を使えば (R)-89 が得られる (Fig. 34b).

Glufosinate (58) は $(S)$-体のみに活性があることから, 大 量調製法が Schulz ら ${ }^{66)}$ によって報告されている。彼らは， $\alpha$-keto acid を $(S)$-58 に変換する酵素 aminotransferase を Escherichia coli $\mathrm{K}-1254$ から単離した. この酵素は基質特異 性で, 4-aminobutyrate-2-ketoglutarate transaminase (EC 2. 6.1.19）と同定された．カラム酵素反応基を用いて 2-oxo-4[(hydroxy)(methyl)phosphino]butyric acidに, 4 倍モルの L-glutamic acid を加えることによって光学純度 $99.9 \%$ 以上 の $(S)-58$ を $50 \mathrm{~g} / l \cdot \mathrm{hr}$ 製造できた (Fig. 38)。また，未反応 の glutamic acid はリサイクルして利用する.ささらに，彼ら はこの transferase を遺伝子工学により, 従来の酵素より 80 倍以上に生産力をあげることに成功した ${ }^{67)}$.

他方, 微生物を用いた不斉還元法には, inabenfide (45) が ある. 219 菌株がスクリーニングされた結果, ケトン体原料 を生物活性型である $(S)-45$ にほぼ $100 \%$ ee で変換する菌 株が得られた。仕込み濃度も高く (15\%), 培養液から換算 して $84 \%$ の変換率であり, さらに培養液から水と有機溶媒 に対する溶解度の差を利用して容易に分離結晶化したこと から工業的規模の生産が可能と考えられる。この菌は Agonomycetalesに属する菌と同定された（Fig. 39） ${ }^{68)}$.

\section{キラルな合成農薬登録における鏡像体の扱いと展望}

以上，キラル農薬の両鏡像体の生物活性と光学活性体の 合成法について述べてきた，現在，上市されている光学活 性農薬は 8 種類にすぎない. 1980 年代に 4 種類であった が, 1990 年代に入ると 4 化合物が追加され，とくに 1995 年

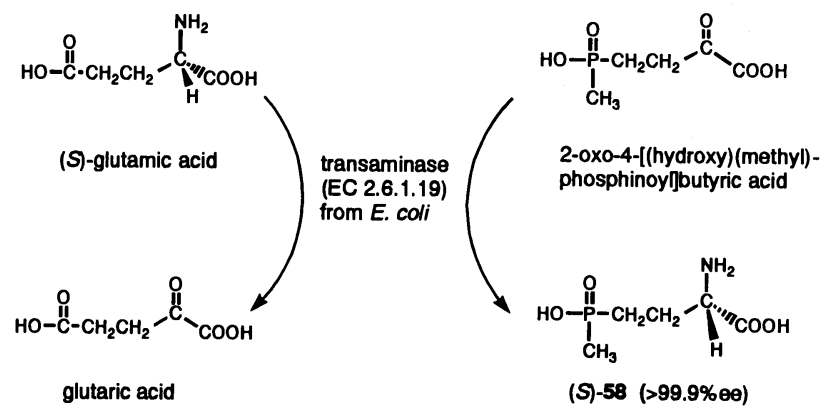

Fig. 38 Enzymatic transamination of $(S)$-glutamate to (S)-glufosinate (58). 


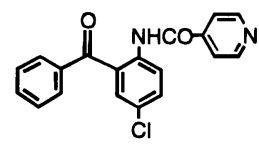

ketone derivative of $\mathbf{4 5}$

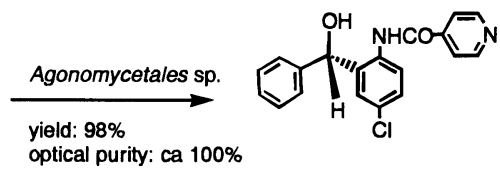

(S)-45
Fig. 39 Microbial reduction of inabenfide ketone derivative to $(S)$-inabenfide (45).

から 1996 年 6 月までの 1 年半の間に新規に登録された 24 種の農薬中, 3 化合物が光学活性体であった。

農薬の登録申請には，農薬取締法に基づいた当該農薬の 品質, 薬効, 薬害, 安全性などのデー夕の提出が義務付け られている，農薬の原体については，性状，製造法および 成分組成を明記する必要がある，とくに成分組成について は有効成分名，構造式および含有量はもちろんのこと，原 体中の混在物についても最新の分析技術により可能な限り 不純物の構造式および含有量を明らかにするとともに，同 定不可能な混在物を含めて総計 $100 \%$ になるように記載し なければならない，たと之ば，構造未知の混在成分につい ても含有量を GC ピークの切取重量法で見かけの值を記 載する．また，混在物の確認方法として，薄層クロマトグ ラムのデータとともに，急性毒性，変異原性のデー夕の提 出が必要である。

また,農薬の安全性評価に関する基準が設定されており， 農薬使用時の安全性および残留農薬（食品中に残留する農 薬㧍よびその関連物質 (不純物，代謝生成物，分解物等)) の安全性については，科学的資料に基づいて実証または確 認されなければならないことになっており，実際には $0.1 \%$ 以上の不純物については，少なくとも化学構造の明示，急 性毒性，変異原性のデータが必要である。

他方, 農薬は安定な農業生産性を維持・向上させるうえ で必須な農業資材である。この場合，「環境保全型農業」の 立場から，少なくとも光学活性体を使用することにより， 投入薬量の減少や毒性の軽減などの安全性の向上が期待で きる．効果のほとんどない混在物や毒性の強い不純物を環 境中に放出することは，環境保全の立場からも慎まなけれ ばならない.すでに述べたように fenvalerateや uniconazole の光学活性型への変換は，これらを証明している.

生体系は光学活性であることから，キラル農薬は薬効の より大きい鏡像体のみが使用されることが本来望まれる。 今後は農薬の新規登録や再登録に際して，キラル化合物に ついてはそれぞれの鏡像体の生物試験のデータが要求され よう. したがって，光学活性体が技術的にも，コスト面で もクリアーできる合成技術が待たれるところである.

本稿の執筆に際して貴重なご助言をいただいた名古屋大学丸 茂晋吾名誉教授に深く感謝の意を表します。

\section{引用 文 献}

1) G. Blaschke, H. P. Kraft \& F. Koehler : Arzneim. Forsch. 29(II), 1640 (1979)

2）目黑寛司：モレキュラー・キラリティー，原 昭二・古賀 憲司・首藤紘一 編, 化学同人, pp. 155-156, 1993

3) S. C. Stinson: Chemical \& Engineering News Oct. 9, 44 (1995)

4) 吉岡宏輔・宮本純之：化学と生物 14, 427 (1976)

5) L. O. Ruzo, L. C. Gaughan \& J. E. Casida : Pestic. Biochem. Physiol. 15, 137 (1981)

6) J. Tessier : Chem. Ind. (London) 1984, 199

7) 吉岡宏輔：有機合成化学協会誌 38, 1151 (1980)

8) M. Miyakado, N. Ohno, Y. Okuno, M. Hirano, K. Fujimoto \& H. Yoshioka: Agric. Biol. Chem. 39, 267 (1975)

9) 松尾憲忠: 続医薬品の開発 第 18 巻 農薬の開発 III, 岩村 俶・上野民夫・鴨下克三 編, 広川書店, pp. 493-514, 1993

10) B. Blessington, N. Crabb \& J. O'Sullivan: J. Chromatogr. 396, 177 (1987)

11）田中俊実・小山田正美・五十嵐桂一・高沢良夫：雑草研究 36, 50 (1991)

12) J. W. Dicks, J. W. Slater \& D. W. Bewick : Proc. Br. Crop Prot. Conf. Weeds 1985, 271

13）鈴木宏一・平田博明・猪飼 隆・坂田五常：農薬誌 16,315 (1991)

14) S. Budavari (ed.) : "Merck Index 12th Edition," Merck \& Co., Inc., p. 3128, 1996

15) T. Miki, Y. Kamiya, M. Fukazawa, T. Ichikawa \& A. Sakurai : Plant Cell Physiol. 31, 201 (1990)

16) N. Minowa, M. Hirayama \& S. Fukatsu: Tetrahedron Lett. 1984, 1147

17）山田富夫·帰山 稔・松井宣夫·米田 渥：農薬誌 12,327 (1987)

18) A. H. M. Raeymaekers, L. F. C. Roevens \& P. A. J. Janssen : Tetrahedron Lett. 1967, 1467

19) A. Hirashima, H. Leader, I. Holden \& J. E. Casida: J. Agric. Food Chem. 32, 1302 (1984)

20) H. Leader \& J. E. Casida : J. Agric. Food Chem. 30, 546 (1982)

21）宮崎昭雄：化学と生物 25, 56 (1987)

22) A. Hubele, W. Kunz, W. Eckhardt \& E. Sturm: "Pesticide Chemistry, Human Welfare and the Environment," ed. by J. Miyamoto \& P. C. Karney, Vol. 1, Pergamon, Oxford, pp. 233-242, 1983

23) M. Takenaka, S. Kimura, T. Tanaka \& T. Wada: $J$. Pesticide Sci. 17, 205 (1992)

24) O. Kirino, Y. Suzuki, K. Yanagi, A. Sogabe \& M. Minobe : J. Pesticide Sci. 8, 429 (1983)

$25)$ B. D. West, S. Preis, C. H. Schroeder \& K. P. Link : J. Am. Chem. Soc. 83, 2676 (1961)

26） 今井康史 - M. Chen - 松本哲男 - P. G. Ray - G. Pews - J. Flake - J. Sencor - A. Hamburg : 雑草研究 39(別)， S-3 (1994)

27) J. H. H. Chan, F. Walker, C. K. Tseng, D. R. Baker \& D. R. Arneklev: J. Agric. Food Chem. 23, 1008 (1975)

28）玉木佳男・野口 浩・杉江 元・刈屋 明 - 新井 茂・大 場正明・寺田考重・勝呂利男・森 謙治：応動昆 24, 221 (1980)

29) W. Kraemer, K. H. Buechel \& W. Draber: "Pesticide Chemistry, Human Welfare and the Environment," ed. by J. Miyamoto \& P. C. Karney, Vol. 1, Pergamon, Oxford, 
pp. 223-232, 1983

30) 佐々木 満：農薬の生有機化学と分子設計, 江藤守総 編, ソフトサイエンス社, pp. 210-222, 1985

31) A. H. B. Deas, G. A. Carter, T. Clark, D. R. Clifford \& C. S. James : Pestic. Biochem. Physiol. 26, 10 (1986)

32) H. Moser, G. Rihs \& H. Sauter : Z. Naturforsch. 37b, 451 (1982)

33) H. Moser, G. Rihs, H. P. Sauter \& B. Boehner: "Pesticide Chemistry, Human Welfare and the Environment," ed. by J. Miyamoto \& P. C. Karney, Vol. 1, Pergamon, Oxford, pp. $315-320,1983$

34) B. Sugavanam : Pestic. Sci. 15, 296 (1984)

35) R. S. Burden, G. A. Carter, T. Clark, D. T. Cooke, S. J. Croker, A. H. B. Deas, P. Hedden, C. S. James \& J. R. Lenton : Pestic. Sci. 21, 253 (1987)

36) W. Koeller : Pestic. Sci. 18, 129 (1987)

37) G. M. Ramos Tombo \& D. Bellus : Angew. Chem. Int. Ed. Engl. 30, 1193 (1991)

38) C. Stehmann \& M. A. de Waard : Pestic. Sci. 44, 183 (1995)

39) 最勝寺俊英・伊藤篤史・熊沢 智・中馬 寞：日本農薬学 会第 20 回大会講演要旨集，東京，p. 95, 1995

40) H. Ohkawa, N. Mikami, Y. Okuno \& J. Miyamoto : Bull. Environ. Contam. Toxicol. 18, 534 (1977)

41) 林 民生：化学 48, 642 (1993)

42）金子秀雄：農薬誌 13, 535 (1988)

43) 大塩裕陸 - 田中鎮也・泉 和夫：植物の化学調節 25,8 (1990)

44）千畑一郎·戸井 二・山田茂樹：化学総説 4 不斉反応の化 学, 日本化学会 編, 東京大学出版会, pp. 233-261, 1974

45) H. Nohira, D. Terunuma \& S. Kobe : Agric. Biol. Chem. 46, 1421 (1982)

46) M. W. Bullock, J. J. Hand \& E. Waletzky: J. Med. Chem. 11, 169 (1968)

47) H. Ohkawa, N. Mikami, A. Mine \& J. Miyamoto: Agric. Biol. Chem. 39, 2265 (1975)

48) A. A. Nomeir \& W. C. Dauterman: Pestic. Biochem.
Physiol. 10, 121 (1979)

49) G. Sakata, K. Makino, K. Kusano, J. Satow, T. Ikai \& K. Suzuki : J. Pesticide Sci. 10, 75 (1985)

50) P. E. Sonnet : J. Org. Chem. 47, 3793 (1982)

51）吉岡宏輔・板谷信重：生理活性物質の不斉合成技術，檜垣 寅雄 編, シーエムシー, pp. 83-113, 1982

52) T. Oritani \& K. Yamashita: Agric. Biol. Chem. 39, 89 (1975)

53) A. Miyazaki, T. Nakamura, M. Kawaradani \& S. Marumo : J. Agric. Food Chem. 36, 835 (1988)

54) G. W. Gorder, O. Kirino, A. Hirashima \& J. E. Casida : $J$. Agric. Food Chem. 34, 941 (1986)

55) M. Ueji \& C. Tomizawa: J. Pesticide Sci. 11, 447 (1986)

56) M. Negawa \& F. Shoji : J. Chromatogr. 590, 113 (1992)

57）牧野成夫：分離技術 25(5), 1 (1995)

58）鈴鴨剛夫・梁尾正美・先砥庸治・村上信二：農薬誌 15,473 (1990)

59) C. E. Berkman \& C. M. Thompson: Tetrahedron Lett. 1992, 1415

60) H. Ohkawa, N. Mikami, K. Kasamatsu \& J. Miyamoto: Agric. Biol. Chem. 40, 1857 (1976)

61) T. Suguro \& K. Mori : Agric. Biol. Chem. 43, 869 (1979)

62) E. Ebert, W. Eckhardt, K. Jaekel, P. Moser, D. Sozzi \& C. Vogel : Z. Naturforsch. 44c, 85 (1989)

63) J. Kaulen: Angew. Chem. Int. Ed. Engl. 28, 462 (1989)

64) T. Aratani, Y. Yoneyoshi \& T. Nagase : Tetrahedron Lett. 1982, 685

65）米由幸夫・鈴鴨剛夫 ·先砥庸治・西岡敏雄（住友化学）：特 開昭 61-18771 (1986)

66) A. Schulz, P. Taggeselle, D. Tripier \& K. Bartsch : Appl. Environ. Microbiol. 56, 1 (1990)

67) K. Bartsch, R. Dichmann, P. Schmitt, E. Uhlmann \& A. Schulz: Appl. Environ. Microbiol. 56, 7 (1990)

68）大石英夫 · 三木卓磨・綱川美香・市川 正・綱川恵之 - 竹 内正毅・遠藤 勲：農化 69, 1323 (1995) 